\title{
CRYSTAL CO-ORDINATION OF THE BARIUM ION
}

\author{
By H. Manohar and S. Ramaseshan, * F.A.SC. \\ (Department of Physics, Indian Institute of Science, Bangalore-12, India) \\ Received Auguat 17, 1964

\section{INTRODUCTION}

THE principles governing the structures of complex ionic crystals have been laid down by Pauling in a set of semi-empirical rules which are named after him. According to Pauling's first rule, a co-ordination polyhedron of anions is formed about each cation, the cation-anion distance being the sum of the radii and the co-ordination number (C.N.) or ligancy of the cation being determined by the radius ratio. The values of the minimum radius ratio required for stability of various co-ordination polyhedra have been worked out and are given in Table I. The other rules relate to the sharing of ions between different co-ordination polyhedra. The most important feature of the Goldschmidt-Pauling concept is that approximately the radius of an ion is constant, and that the anion-cation radius ratio plays an important part in determining the final crystal structure.

In the case of barium compounds the ratio of the "univalent" radii of $\mathrm{Ba}^{2+}$ to $\mathrm{O}^{2-}$ is $1 \cdot 53 / 1 \cdot 76=0 \cdot 87$, the anions in most of the ionic complexes being oxygen ions. $\mathrm{Ba}^{2+}$, therefore, should normally exhibit a co-ordination number of nine or ten. However, following the identification of the icosahedral twelve co-ordination of barium in $\mathrm{Ba}\left(\mathrm{ClO}_{4}\right)_{2} \cdot 3 \mathrm{H}_{2} \mathrm{O}$ by Mani and Ramaseshan ${ }^{2}$ and the eight-fold antiprism co-ordination in $\mathrm{Ba}(\mathrm{OH})_{2} .8 \mathrm{H}_{2} \mathrm{O}^{2,4}$ by the present authors, it was considered worthwhile to undertake a systematic study of the crystal co-ordination of the barium ion to find out whether it displays any other co-ordinations, and if so, to identify the new co-ordination polyhedra and determine their shapes and geometry.

A survey of the structures of barium compounds in the literature revealed that the shapes of the co-ordination polyhedra were identified only when they were of the standard symmetric type such as given in Table I. In cases where the co-ordination numbers were unusual like seven, ten or eleven, beyond giving the numbers and distances of the nearest atoms, no attempts were

- Preseat addreas: Department of Phycics, Indian Institute of Technology, Madras 36 (tadia). 
generally made to investigate the shapes of the co-ordination polyhedra. In many cases the nearest neighbours alone at approximately the same distance from the cation were considercd for the purpose of crystal co-ordination, the investigators having been reluctant even to give the number of next nearest

\section{TABLE I}

Values of the minimum radius ratio for stability of various co-ordination polyhedra

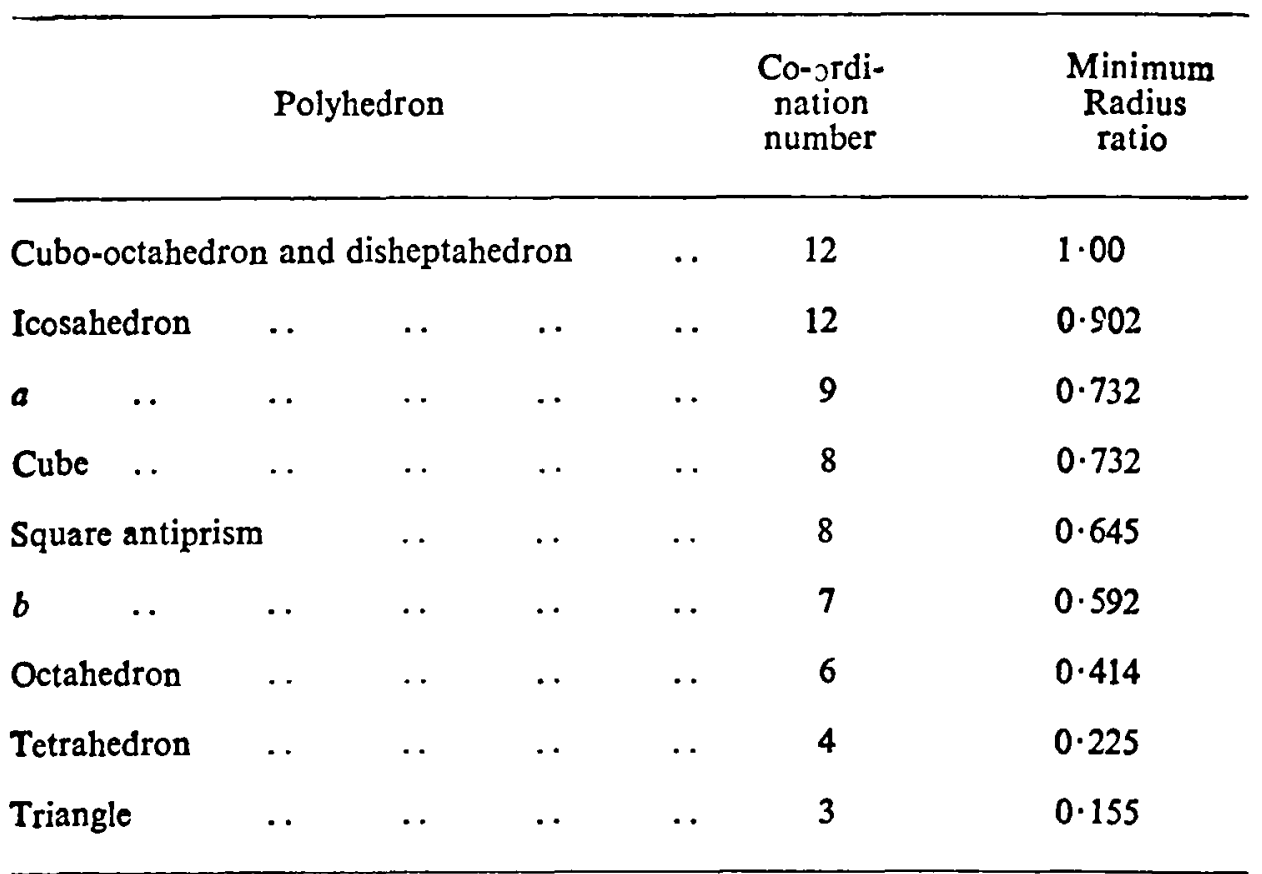

(a) This polyhedron with 18 equal faces is obtained by adding 3 atoms at the centres of the vertical faces of a right triangular prism.

(b) This polyhedron is obtaincd by adding an atom at the centre of a face of an octahedron.

neighbours. In the present stlidy, all the inter-atcmic distarces were calculatcd and the positions of atcms co-crdinating barilm wise plottcd in the most suitable projection. The heights of ihcsc atcms wicie icfrescntcd by metal rods cut to appropriate lengths and a carcful strdy of these modcls led to the identification of some new co-ordination folyhedra. The rcsults obtaincd in the investigation are prescnted in this papcr. In the accompanying figures, one cxample (in a $\mathrm{fcw}$ cascs, $1 \mathrm{wo}$ ) of the actual atomic fositions of the co-ordinating atoms is given for each tyfe of co-ordination and 
alongside the idealised polyhedron has been drawn. Only ionic compounda have been considered in this revicw.

\section{OCtahedral CO-ORdination (C.N. 6 )}

Simple ionic compounds having the formula $\mathrm{BaX},{ }^{b}$ were $\mathrm{X}$ is $\mathrm{O}, \mathrm{S}$, se and $\mathrm{Te}$, as also barium imide $\mathrm{BaNH},{ }^{6}$ crystallise in the cubic rocksalt structure with the barium ion exhibiting a six-fold octahcdral co-ordination. The co-ordination polyhcdron round barium in the oxide is shown in Fig. 1. In the system $\mathrm{BaCO}_{2}-\mathrm{CaCO}_{3}$, solid solutions are formed which are refortcd? to show the aragonite structure when the proportion of $\mathrm{BcCO}_{3}$ varics between 100 per cent to 80 per cent and the calcite structure, for $\mathrm{B}_{2} \mathrm{CO}_{3}$ less than 60 per cent. In the latter case, therefore, $\mathrm{Ba}^{2+}$ is co-ordinatcd octahcdrally by six oxygens. The low temperature forms of barium silicate $\mathrm{BiSiO}_{3}$ and barium germanate $\mathrm{BaGCO}_{3}$ belong to the structure tyfe fscucowollastonite a-CaSiO (Hilmer). $^{8}$ The structure and symmetry of a-CaS.O $\mathrm{O}_{3}$ have bcen

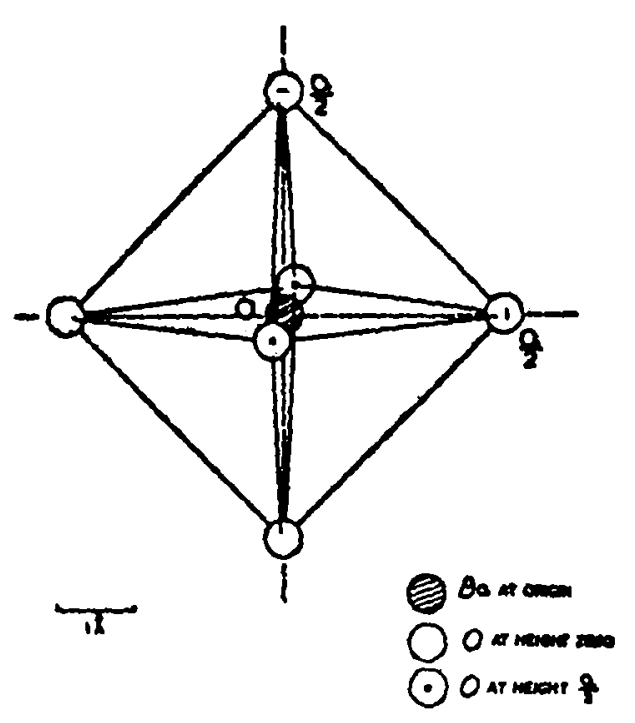

1

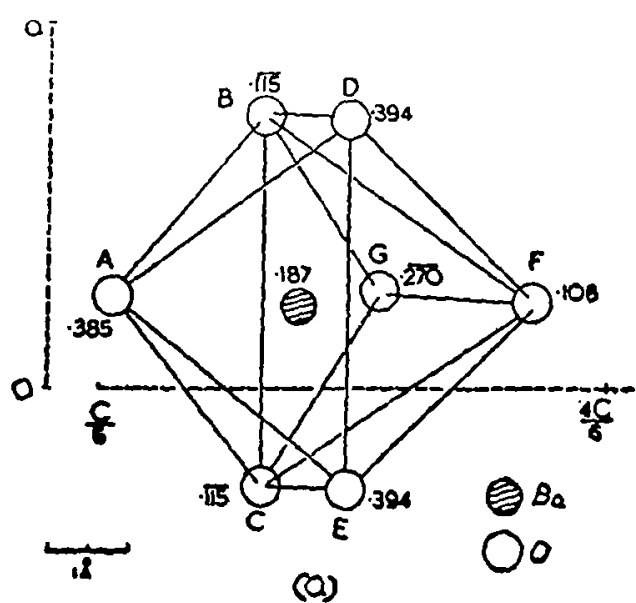

(a)

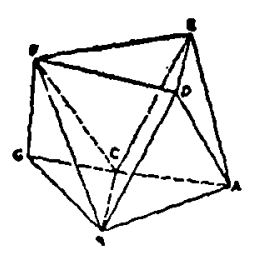

2

Fie. 1. Cctahedral co-ordination around $\mathrm{Ba}^{2+}$ icn in $\mathrm{EaO}$.

Fro. 2. Co-ordination polyhedron (Octahedron +1 ) in the high temperature form of $\mathrm{BaGeO}_{2}$. In this and following figures of this paper, the numbers by the side of atoms indicate heights in fructional_co-ordinates along the axis of projection. 
derived from an $\mathrm{X}$-ray analysis ${ }^{2}$ of the isostructural synthetic compound $\mathrm{SrGeO}_{3}$, crystals of which are more easily obtained, where the $\mathrm{Sr}^{2+}$ ions are found to be at the centres of octahedra of $O$ atoms. Therefore, barium displays an octahedral co-ordination in the above-mentioned two compounds.

A slightly distorted octahedral environment for barium has also been observed in more complex structures-as for example, in the silicate benitoite, ${ }^{10}$ $\mathrm{BaTisi}_{3} \mathrm{O}_{9}$, in monoclinic barium peroxide monohydroperoxidate $\mathrm{BaO}_{2} \cdot \mathrm{H}_{2} \mathrm{O}_{2}{ }^{11}$ and in the hexagonal meta-antimonate $\mathrm{BaSb}_{2} \mathrm{O}_{6} \cdot{ }^{12} \mathrm{~A}$ number of complex alkaline-earth molybdates, tungstates and uranates ${ }^{13,14}$ like $\mathrm{Ba}_{3} \mathrm{WO}_{6}, \mathrm{Ba}_{3} \mathrm{UO}_{6}$, $\mathrm{Ba}_{2} \mathrm{CaWO}_{6}, \mathrm{Ba}_{2} \mathrm{CaMoO}_{6}, \mathrm{Ba}_{2} \mathrm{SrUO}_{6}, \mathrm{Sr}_{2} \mathrm{BaUO}_{6}$ crystallise with the ideal cubic $\left(\mathrm{NH}_{4}\right)_{3} \mathrm{AlF}_{6}$ structure or with slightly distorted variations. This can be referred to as the cryolite structure ${ }^{15}$ with the general formula $A_{3} B X_{6}$ where one-third of the $A$ atoms are in octahedral holes in a cubic close-packed $A_{2} X_{6}$ assembly. The other two-thirds of the $A$ atoms are surrounded by twelve equidistant $\mathrm{X}$ ions.

\section{Co-ordination Number SEven}

Wells ${ }^{16}$ describes three arrangements for seven-fold co-ordination of cations. The odd atom $\mathrm{G}$ is placed above the centre of one face BCF of an octahedron [Fig. $2(b)$ ], which is distorted chiefly by separating the atoms at the corners of this face; or beyond the centre of one of the rectangular faces ADCF of a trigonal prism [Fig. $3(b)$ ] with some consequent distortion. The former arrangement has been found in the high temperature form of $\mathrm{BaGeO}_{3}{ }^{8}$ [Fig. $2(a)$ ], while the latter is present for both the non-equivalent barium ions in $\mathrm{Ba}_{2} \mathrm{ZnS}_{8}{ }^{17}$. The arrangement of sulphur atoms round $\mathrm{Ba}^{2+}$ at $0.326,0.019,0.250$ (in fractional co-ordinates) is shown in Fig. $3(a)$. In the third case, the co-ordinating atoms occupy the vertices of a pentagonal bipyramid. A modified form of this co-ordination polyhedron has been identified in rhombohedral $\mathrm{NiO} .3 \mathrm{BaO}^{18}$ [Fig. $4(a)$ ]. Here the pentagon is not plane, one atom $\mathrm{A}$ having been moved out. The idealised polyhedron is shown in Fig. 4 (b).

\section{CO-ORDINATION NUMBER EJGHT}

The cubic co-ordination of eight fluorines round the barium ion manifests itself in barium fluoride, ${ }^{19} \mathrm{BaF}_{2}$, which is isotypic with cubic fluorite. Recently, the structure and dielectric properties of a series of tetragonal compounds having the general formula $\mathrm{Ba}_{x}\left(\mathrm{Ti}_{8-x} \mathrm{Mg}_{x}\right) \mathrm{O}_{18}$, where $x$ coukd be varied over a wide range between 0.67 and 1.14 , have been described. ${ }^{20}$ 

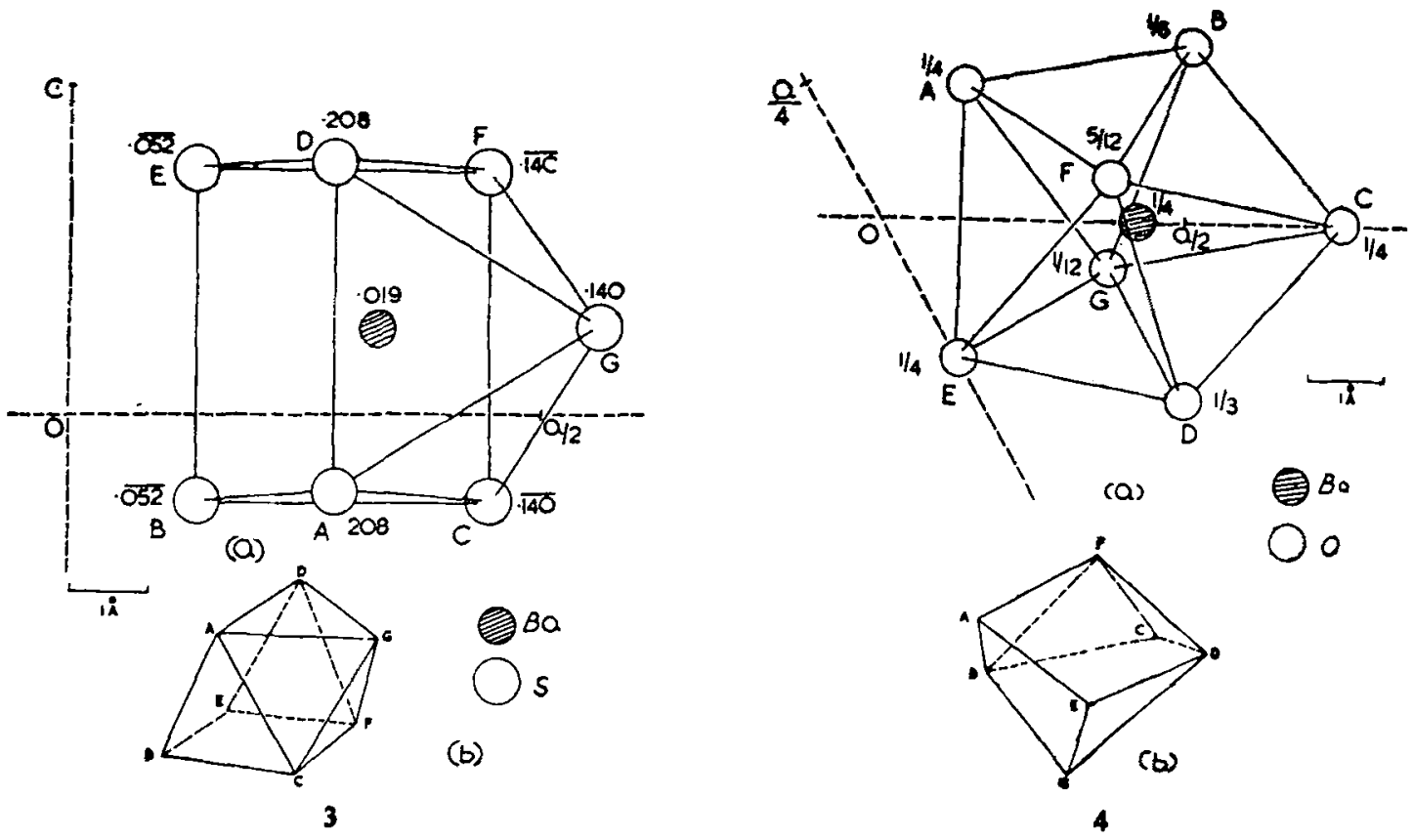

Fra. 3. Co-ordination polyhedron of sulphurs (Trigonal prism one face-centred) round Bat ion in Ba, ZaS.

Fro. 4. Co-ordination polyhedron (Modified pentagonal pyramid) in NiO.3BaO.

The barium ions are reported to be surrounded by eight oxygens at the corners of a highly distorted cube. The co-ordination polyhedron (Fig. 5) when drawn was actually found to be a square prism with sides $3.7 \AA, 3 \cdot 7 \AA$ and $3 \cdot 0 \AA$.

Eight-fold co-ordination polyhedra which are more satisfactory than the cube from the point of stereochemistry are reported ${ }^{21}$ to be the dodecahedron with triangular faces, the square Archimedean antiprism and the triangular prism with two of its rectangular faces centred. The Archimedean antiprism ${ }^{22}$ is obtained when the top square face of a cube is rotated with respect to its bottom face by $45^{\circ}$. The resulting figure is bounded by eight triangular and two square faces and all the sixteen edges are equal. It has a maximum symmetry of $82 \mathrm{~m}$. The antiprism arrangement of oxygens in a slightly distorted form is present in barium hydroxide octahydrate $\mathrm{Ba}(\mathrm{OH})_{2} \cdot 8 \mathrm{H}_{2} \mathrm{O}$, whose crystal structure has recently been solved ${ }^{3,4}$. It has also been subsequently identified by the present writers for one of the two non-equivalent barium ions in the hydrated barium silicate $\mathrm{BaO} . \mathrm{SiO}_{2} \cdot 6 \mathrm{H}_{8} \mathrm{O} . .^{23}$ In this structure, the waters and oxygen atoms are 
indistinguishable. The co-ordination polyhedra for the two compounds are shown in Figs. 6 and 7 respcctively. As Mani and Ramaseshan ${ }^{2}$ have

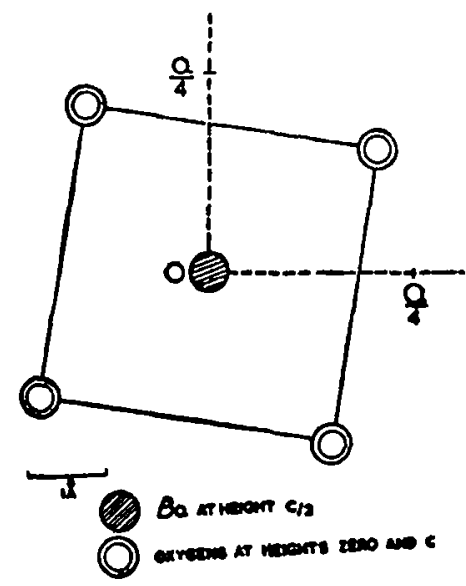

5

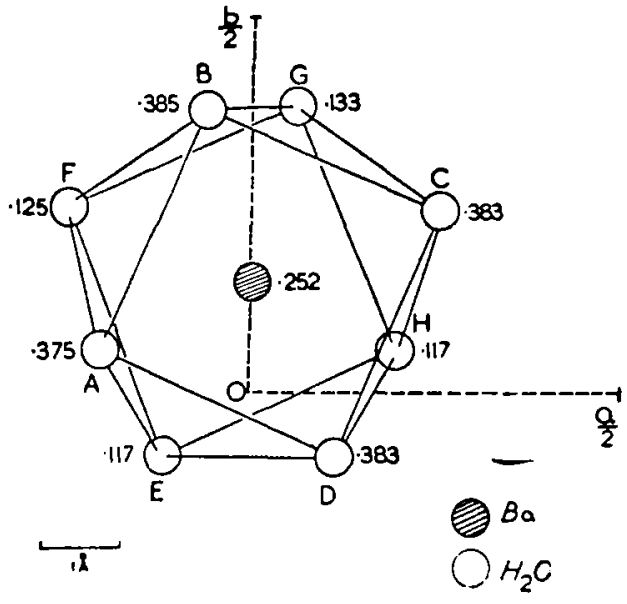

6

Fre. 5. Square prismatic co-ordination of barium in $\mathrm{Ba}_{0}\left(\mathrm{Ti}_{\mathbf{g}_{-}} \mathrm{Mg}_{\mathrm{g}_{0}}\right) \mathrm{O}_{\mathbf{1 s}}$.

Fro. 6. Co-ordination polyhedron (Square antiprism) in $\mathrm{Ba}(\mathrm{OH})_{2} .8 \mathrm{H}_{2} \mathrm{O}$.

pointed out, the trigonal prism with two faces centred [Fig. $8(b)$ and $(d)$ ] can be considered as a highly distorted antiprism [Fig. $8(a)$ and $(c)$ ]. The distortion consists in converting the square face $\mathrm{ABCD}$ of the antiprism into a rhombus and bending it along the diagonal $\mathrm{BD}$ to form two triangles $A B D$ and $B D C$. The vertices $A$ and $C$ now centre the rectangular faces BDEF and BDHG of the triangular prism BDEFGH.

The triangular dodecahedron, also called the bisdisphenoid, is shown in Fig. $9(c)$. This figure can be derived from a cube by stretching the top and bottom square faces $\mathrm{ABCD}$ and EFGH along perpendicular face diagonals $B D$ and EG to obtain two rhombuses. The shorter diagonals $A C$ and $\mathrm{FH}$ are now moved away from the centre of gravity of the solid so that each thombus gives rise to two equilateral triangles which are not in the same plane. The resulting solid is bounded by twelve equilateral triangles. The structure of the silicate Gillespite $\mathrm{BaFeSi}_{4} \mathrm{O}_{10}{ }^{24}$ consists of tetragonal zig-zag layers of $\mathrm{SiOO}_{3 / 2}$ tetrahedra sharing corners. The barilim atoms are reported to lie between the layers with a distorted cubic co-ordination. However, when the co-ordinating oxygen atoms were plotted, as shown in Fig. $9(a)$ and $(b)$, they were found to occupy the corners of a dodecahedron. Barium molybdate $\mathrm{BaMoO}_{4}$ and tungstate $\mathrm{BaWO}_{4}$ are both isotypes of tetragonal scheelite $\mathrm{CaWO}_{4}{ }^{25}$ The co-ordination polyhedron of eight 


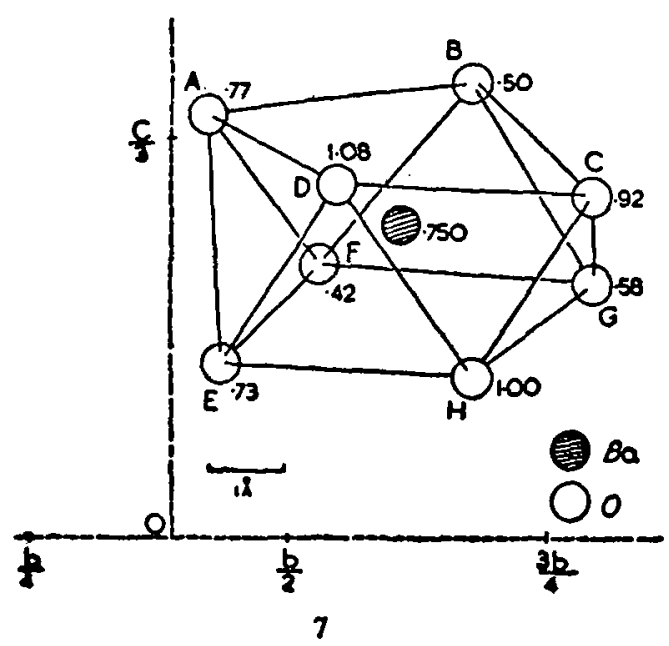

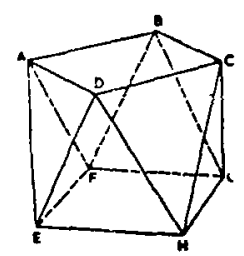

(a)

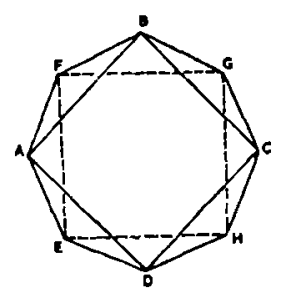

(C)

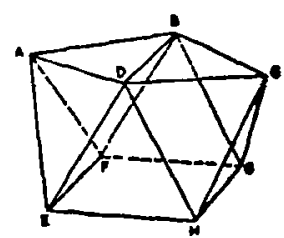

(b)

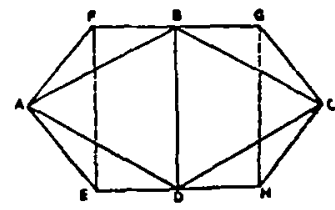

(d)

Fro. 7. Square antiprism co-ordination round one of the barium ions in $\mathrm{BaO} \cdot \mathrm{SiO}_{2} \cdot 6 \mathrm{H}_{2} \mathrm{O}$.

Fio. 8. Relationship between the square antiprism $[(a)$ and $(c)]$ and the trigonal prism with two prism faces centred $[(b)$ and $(d)]$.

oxygens in the scheelite type can be described as a distorted dodecahedron. In the structure of $\mathrm{BaZnO}_{2},{ }^{26}$ the barium ion is reportcd to be surrounded by four oxygens at relatively short distances $(2 \times 2.64 \AA, 2 \times 2.68 \AA)$ in the form of a distorted bisphenoid, ${ }^{27}$ which is a closed four-faced wedge-like solid resembling the tetrahedron but possessing no planes of symmetry. If two more at a larger distance of $2.97 \AA$ are considered, the six are reported to form a strongly distorted octahedron. It was, however, felt that the barium ion should have a more symmetric co-ordination. When the two rext nearest neighbours $3 \cdot 36 \AA$ away were also included and the eight co-ordinating atoms plotted, a slightly distorted bisdisphenoidal arrangement could be identified. The reported ${ }^{28}$ similarity in the powder diagrams of $\mathrm{BaMnO}_{2}$, $\mathrm{B}_{\mathrm{i}} \mathrm{CoO}_{2}$ and $\mathrm{Bi}_{\mathrm{inO}}$ leads one to expect the same co-ordination polyhedron for $\mathrm{Ba}^{2+}$ in the first two substances as well.

A new eight co-ordination, shown in Fig. $10(a)$, has been identified in barium uranate, $\mathrm{BaUO}_{4}{ }^{29}$ The idealised polyhedron [Fig. $10(b)$ ] can be described in terms of a plane pentagon MLSTN whose vertices are joined to a point $R$ on one side and two others $O$ and $P$ on the other, the line $O P$ being parallel to the plane of the pentagon. It is interesting to observe that 


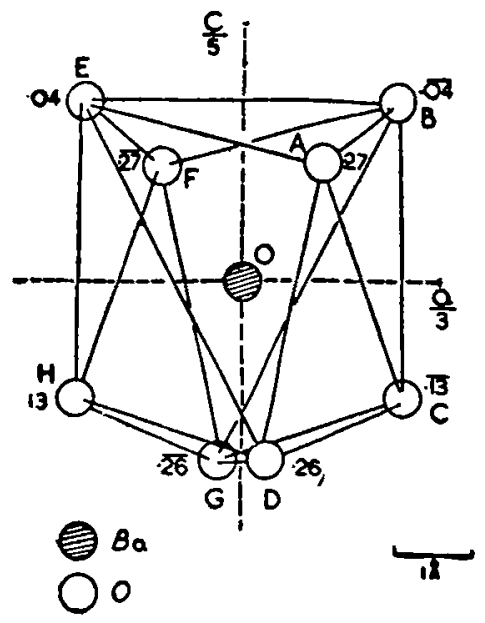

(O)

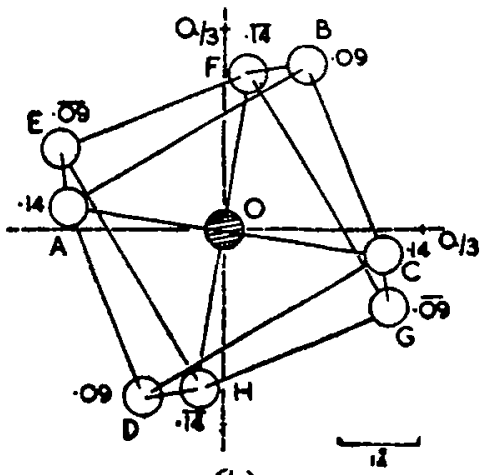

(b)

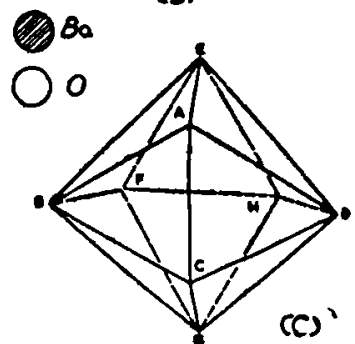

Fie. 9. Co-ordination polyhedron (Triangular dodecahedron) round barium in $\mathrm{BaFeSi}_{4} \mathrm{O}_{\mathbf{2 0}}$.
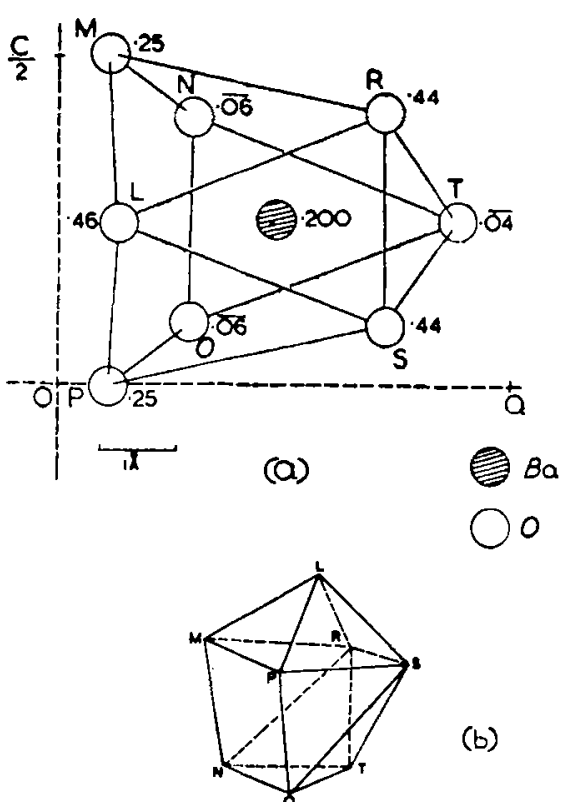

10

(b)

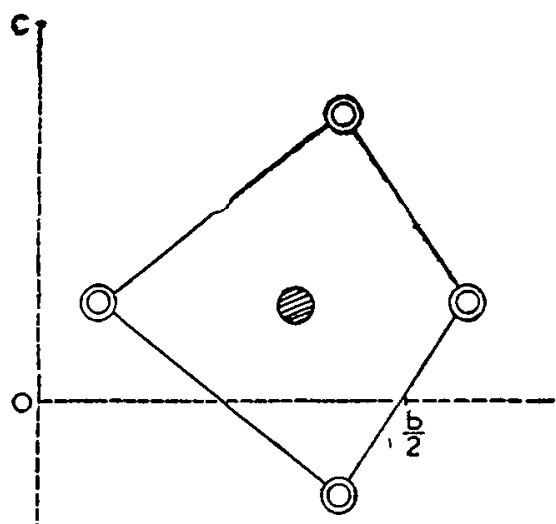

(C) $\mathrm{OAT}_{\text {Heschts }} \pm \frac{\mathrm{a}}{4}$

11

Frs. 10. New eight-fold co-ordination of $\mathrm{Ba}^{\mathrm{l}+}$ in $\mathrm{BaUO}$, (see text).

Fro. 11. Co-ordination polybedron (Quadrilateral prism) in NiO.BaO. 
the points OPLRT also form a plane pentagon approximately perpendicular to the first.

In barium permanganate $\mathrm{Ba}\left(\mathrm{MnO}_{4}\right)_{2}{ }^{30}$ the eight oxygens co-ordinating the barium form an orthorhombic prism while in $\mathrm{NiO}-\mathrm{BaO}^{18}$ they form a quadrilateral prism as shown in Fig. 11.

\section{NINE-FOLD CO-ORDINATION}

The halides of barium, $\mathrm{BaX}_{2}{ }^{81}(\mathrm{X}=\mathrm{Cl}, \mathrm{Br}, \mathrm{I})$ crystallise in the structure of $\mathrm{PbCl}_{\mathbf{2}}$. Here each barium is surrounded by nine halogen ions, six at the apices of a trigonal prism and the remaining three beyond the centres of the three prism faces [Fig. $12(b)$ ]. This appears to be the most common arrangement for nine-fold co-ordination. It is identified in barium orthoplumbate $\mathrm{Ba}_{2} \mathrm{PbO}_{4}$ and orthostannate $\mathrm{Ba}_{2} \mathrm{SnO}_{4},{ }^{32}$ which are isomorfhous with $\mathrm{K}_{2} \mathrm{NiF}_{4}$ and also in $\mathrm{SrCl}_{2} \cdot 6 \mathrm{H}_{2} \mathrm{O}^{33}$ with which $\mathrm{BaI} .6 \mathrm{H}_{2} \mathrm{O}^{34}$ is isotypic. In the latter compounds nine waters make up the co-ordination polyhedron. On the other hand, in $\mathrm{BaCl}_{2} \cdot \mathrm{H}_{2} \mathrm{O}^{35}$ and $\mathrm{BaBr}_{2} \cdot \mathrm{H}_{2} \mathrm{O}^{36}$ which are isomorphous, six halogen ions are at the corners of the triangular prism while two waters and one halogen form the face centres. The same co-ordination polyhedron is formed by six oxygens and three waters in the orthorhombic form of barium pentathionate dihydrate $\mathrm{BaS}\left(\mathrm{S}_{2} \mathrm{O}_{3}\right)_{2} \cdot 2 \mathrm{H}_{2} \mathrm{O},{ }^{37}$ in barium selenopentathionate dihydrate $\mathrm{BaSe}\left(\mathrm{S}_{2} \mathrm{O}_{3}\right)_{2} \cdot 2 \mathrm{H}_{2} \mathrm{O}^{38}$ and in barium tetrathionate dihydrate $\mathrm{BaS}_{4} \mathrm{O}_{6} .2 \mathrm{HO}^{39}$

The structure of $\mathrm{BaCl}_{2} \cdot 2 \mathrm{H}_{2} \mathrm{O}^{40}$ consists of identical puckered $\left(\mathrm{BaCl}_{2} \cdot 2 \mathrm{H}_{2} \mathrm{O}\right)_{n}$ layers parallel to the $a-c$ plane. Each barium is reported to be surrounded by four chlorine ions at distances between $3 \cdot 11 \AA$ and $3.27 \AA$ and four waters at distances between $2.78 \AA$ and $2.82 \AA$ in a distorted cubic configuration. In plotting the neighbours of barium [Fig. $12(a)$ ], however, it was found that the co-ordination number was nine and not eight as reported. This was because only the atoms within a layer had been considered, the chlorine $\mathbf{K}$ in the next layer at a distance $3 \cdot 38 \AA$ from $\mathrm{Ba}^{2+}$ having been overlooked. When this is also taken into account, the same co-ordination polyhedron discussed before is found to result.

The nine-fold co-ordination polyhedron [Fig. 12(b)] consisting of a trigonal prism BDEFGH with the three prism faces centred by atoms A, C and $\mathrm{K}$ can also be looked at from a different point of view. It can be considered as a pentagonal pyramid D-ABCHE, D being the apex, placed over a triangle $F G K$ in such a way that the vertices of the triangle $F, G$ and $K$ lie midway below $\mathrm{AB}, \mathrm{BC}$ and $\mathrm{EH}$ respectively. $\AA$ slightly modified form of the latter description has been identified in barium platinum titanium 
oxide $\mathrm{Ba}_{4} \mathrm{Ti}_{2} \mathrm{PtO}_{10}{ }^{.2}$ The unit cell contains two groups of non-equivalent barium atoms, and the arrangement of oxygens round barium at $0.146,0.473$, $O$ is shown in Fig. $13(a)$. Here the atoms F, G, K at the vertices of the triangle lie directly below the vertices $A, B, C$ respectively of the pentagon. The idealiscd folyhedron is shown in Fig. $13(b)$.
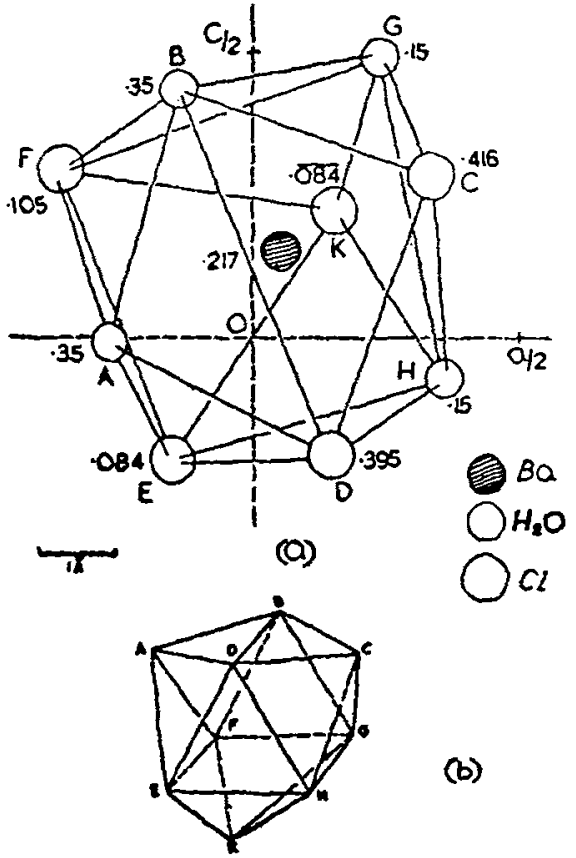

12
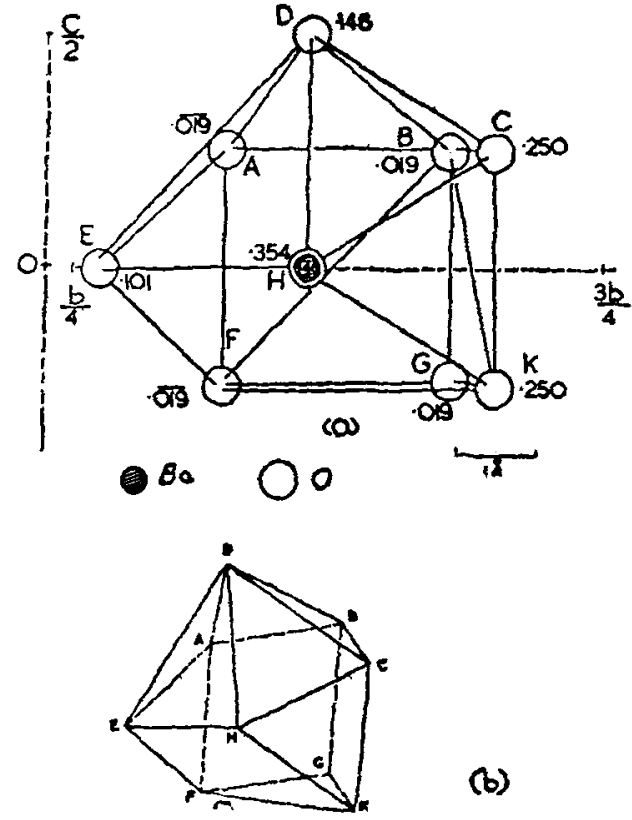

13

Fro. 12. Co-ordination polyhedron (Trigonal prism with three faces centred) in $\mathrm{BaCl}_{2} \cdot 2 \mathrm{H}_{3} \mathrm{O}$.

Fis. 13. Co-ordination of oxygens round one of the barium ions in $\mathrm{Ba}_{4} \mathrm{Ti}_{2} \mathrm{PtO}_{10}$ (see text).

A new nine-fold co-ordination, shown in Fig. $14(a)$, has been identified in the mineral paracelcian $\mathrm{BaAl}_{2} \mathrm{Si}_{2} \mathrm{O}_{8} \cdot{ }^{22}$ The polyhedron, idealised in Fig. $14(b)$, can be described as a cube whose one edge MP has been elongated to make room for one more atom $G$ situated beyond MP to co-ordinate the metal ion at the centre. The other polymorphic modification, barium felspar or celcian, heving the same formula, in which the configuration of oxygens is reported to be cxactly similar has presumably the same coordination polyhedron of oxygen atoms round barium. Solid solutions of $\mathrm{BaCO}_{3}$ and $\mathrm{CaCO}_{3}$ crystallise, as mentioned already, in the structure of aragonite when the content of $\mathrm{BaCO}_{3}$ varies between 80 per cent and 100 per cent." In this structure ${ }^{45}$ as also in the silicate sanbornite $\mathrm{BaSi}_{2} \mathrm{O}_{5}{ }^{48}$ the 
above-mentioned polyhedron has been observed. It may be noted in passing that an investigation ${ }^{47}$ of the high temperature phases of alkaline-earth carbonates reveals the interesting fact that $\mathrm{BaCO}_{3}$ changes from the orthorhombic aragonite type to the hexagonal calcite type at $803^{\circ} \mathrm{C}$. and the cubic sodium chloride type of structure at $976^{\circ} \mathrm{C}$. The transitions are relatcd to the rotational activity of the carbonate ions.
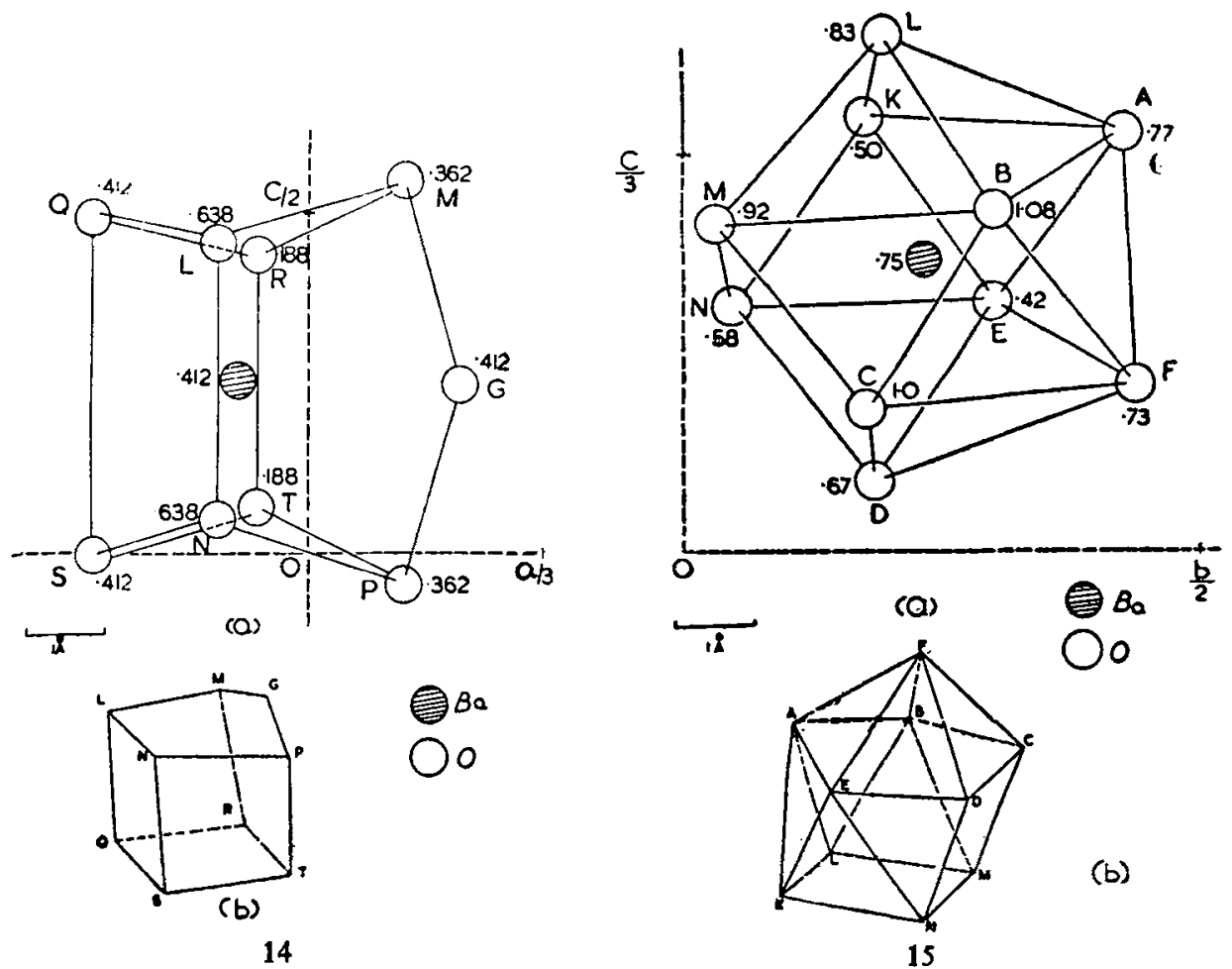

14

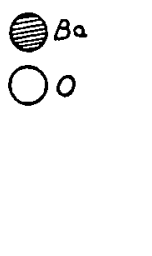

Fro. 14. Nine-fold co-ordination of barium in paracelcian, $\mathrm{BaAl}_{2} \mathrm{Si}_{2} \mathrm{O}_{8}$ (see text). toxt).

Fia. 15. Ten-fold co-ordination around the second barium ion in $\mathrm{BaO} . \mathrm{SiO}_{2} .6 \mathrm{H}_{2} \mathrm{O}$ (see

\section{CO-ORDination Number TeN}

Wells $^{\mathbf{t}}$ has pointed out that co-ordination polyhedra less symmetrical than those commonly known are found in some crystals and has cited the example of $\mathrm{LaF}_{3}$ for eleven-fold co-ordination. However, the shapcs of the polyhedra do not appear to have been investigated hitherto. In the hydrated silicate $\mathrm{BaO} . \mathrm{SiO}_{2} \cdot 6 \mathrm{H}_{2} \mathrm{O},{ }^{23}$ there are two non-equivalent barium ions in the unit cell, one of which, as mentioned earlier, exhibits an eight-fold coordination. The other barium, however, is co-ordinated by ten oxygens (either hydroxyl groups or waters). The polyhedron (Fig. 15), is made up of 
two regular pentagonal pyramids E-AFDNK and B-AFCML sharing an edge AF. The solid has two other pentagonal pyramids with apices at $\mathrm{A}$ and $F$ and two square faces KLMN and MNDC. The figure can also be described as consisting of a pentagonal pyramid F-ABCDE placed over a square KLMN. This co-ordination polyhedron has also been found in a slightly distorted form for all three non-equivalent barium ions in barium hydrogen orthophosphate $\mathrm{BaHPO}_{4}{ }^{49}$ and also in the silicate harmotone $\mathrm{Ba}_{2} \mathrm{Al}_{4} \mathrm{Si}_{12} \mathrm{O}_{32} .12 \mathrm{H}_{2} \mathrm{O} .^{50}$

The cations in rhombohedral normal orthophosphate of barium $\mathrm{Ba}_{3}\left(\mathrm{PO}_{4}\right)_{2}{ }^{\mathrm{b1}}$ have two kinds of environment. Barium ions of one kind, e.g., that at $0,0,0 \cdot 208$ (in hexagonal indexing) are co-ordinated by ten oxygens as shown in Fig. 16(a). The co-ordination polyhedron consists of a hexagonal pyramid placed over a triangle. Other compounds crystallising in this structure can be indicated by the formula $\mathrm{Ba}_{3}\left(\mathrm{XO}_{4}\right)_{2}{ }^{52}$ where $\mathrm{X}=\mathrm{As}$, $\mathrm{V}, \mathrm{Cr}, \mathrm{Mn}$.

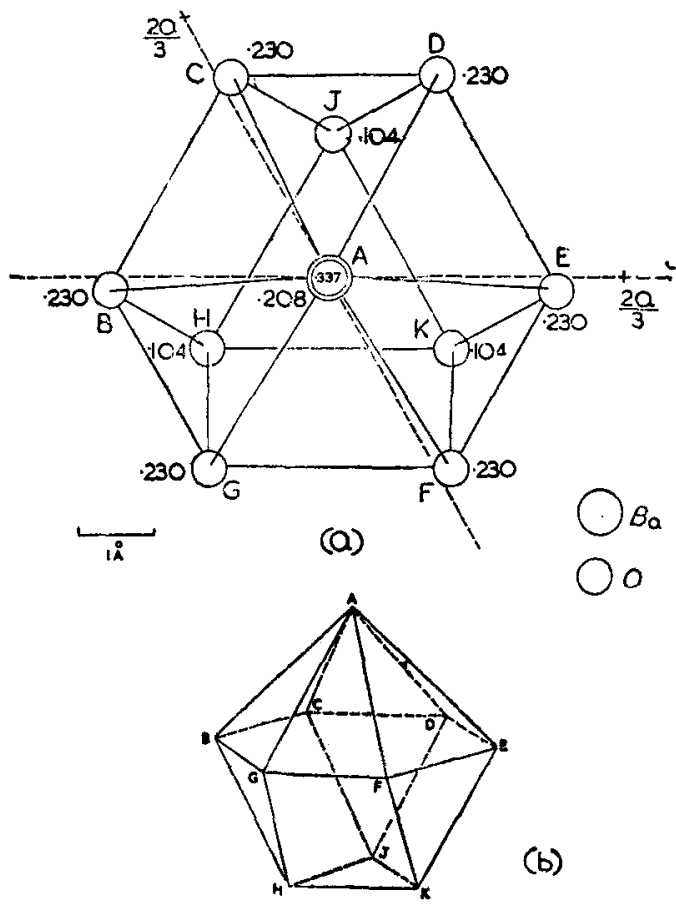

Frc. 16. Co-ordination polyhedron round $\mathrm{Ba}_{1}{ }^{2+}$ in $\mathrm{Ba}_{2}\left(\mathrm{PO}_{4}\right)_{2}$ (see text).

The structure of barium peroxide $\mathrm{BaO}_{2}{ }^{83}$ can be regarded from the geometrical point of view as derived from the rocksalt structure by replacing the $\mathrm{Na}^{+}$and $\mathrm{Cl}^{-}$by barium and peroxide ions respectively. Therefore, the 
barium ion is octahedrally co-ordinated by six peroxide groups. The C.N. is, however, ten. The co-ordination polyhedron [Fig. $17(a)$ ] consists of eight oxygens belonging to four peroxide groups which form a flat square prism of sides $3 \cdot 81 \AA$ and height $1.49 \AA$, which is the $0-0$ distance in the peroxide group, and two more which lie beyond the square faces. Barium carbide $\mathrm{BaC}_{2}{ }^{\text {s4 }}$ also displays the same atomic arrangement.

In barium tetratitanate $\mathrm{BaTi}_{4} \mathrm{O}_{9}{ }^{55}$ it has been pointed out by the investigators of the structure that the metal ion has ten co-ordinating oxygens at the corners of a pentagonal prism. The co-ordination polyhedron for this compound is shown in Fig. $18(a)$.

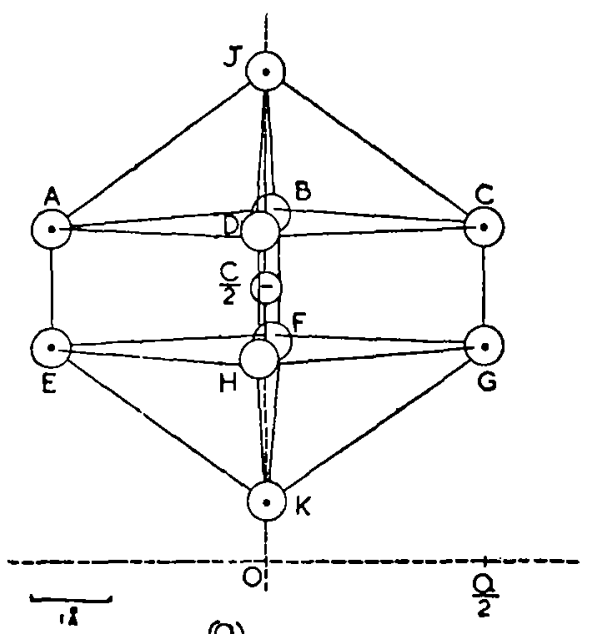

(a)

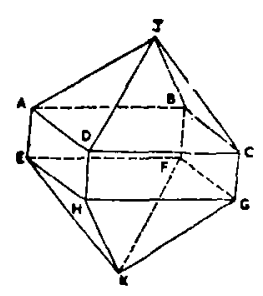

17
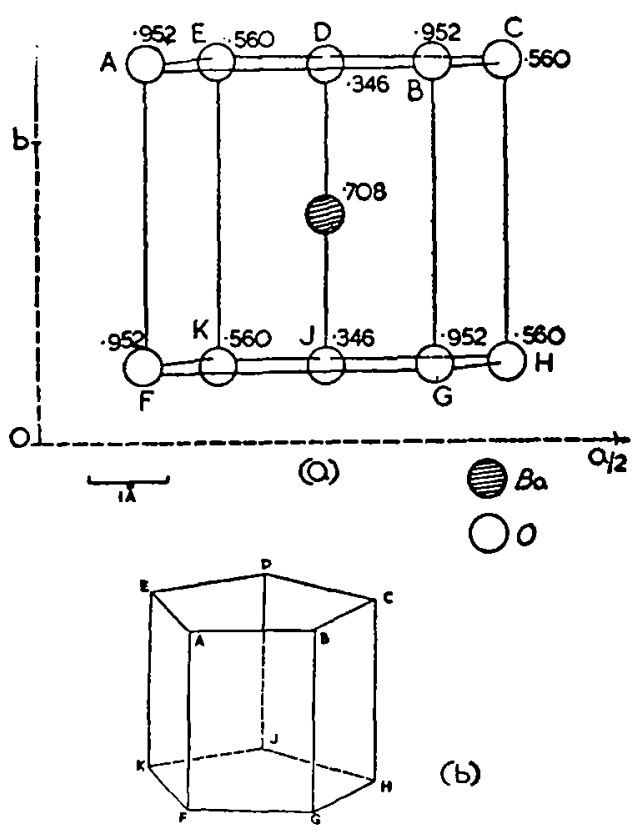

18

FIG. 17. Co-ordination polyhedron in $\mathrm{BaO}_{2}$.

Fio. 18. Co-ordination polyhedron (Pentagonal prism) in $\mathrm{BaTi}_{4} \mathrm{O}_{8}$ ).

\section{ELEVEN-FOLD CO-ORDINATION}

An interesting geometric figure [Fig. $19(a)$ ] has been identified as the co-ordination polyhedron around barium in barium thiosulphate mono- 
hydrate $\mathrm{BaS}_{2} \mathrm{O}_{3} \cdot \mathrm{H}_{2} \mathrm{O} .56$ In this structure barium has eleven nearest neighbours consisting of nine oxygens and two sulphurs. The idealised solid [Fig. $19(b)$ ] consists of a plane pentagon ABCDE, with two triangles FGH and KLM oriented in the same manner, placed symmetrically above and below it, and is bounded by eighteen triangular faces.

Wells ${ }^{57}$ reports that the 'tysonite' structure of $\mathrm{LaF}_{8}$ is adopted among others by certain complex fluorides of barium like $\mathrm{BaThF}_{6}$ and $\mathrm{BaUF}_{6}$. In tysonite, the $\mathrm{La}^{3+}$ ion is reported to have five equidistant nearest neighbours at a distance $2 \cdot 36 \AA$, at the apices of trigonal bipyramid. The next nearest neighbours are six more fluorines at the corners of a trigonal prism at a distance of $2.70 \AA$. All the eleven atoms, when taken together, are found to form the above-mentioned polyhedron. In fact, in Fig. $19(b)$, it is easy to see that the triangular faces of the prism are FEK and GDL and the vertices of the bipyramid A-BHM-C.

In barium chlorate monohydrate $\mathrm{Ba}\left(\mathrm{ClO}_{3}\right)_{2} \cdot \mathrm{H}_{2} \mathrm{O}^{58}$ and the isomorphous $\mathrm{Ba}\left(\mathrm{BrO}_{3}\right)_{2} \cdot \mathrm{H}_{2} \mathrm{O}^{50}$ the co-ordination polyhedron (Fig. 20) of ten oxygens and one water can be described as a square placed over a hexagonal pyramid, the hexagon being puckered.

\section{Co-ordination Number Twelve}

Twelve-fold co-ordination is exhibited in a variety of ways in barium compounds. A large number of compounds crystallise with the cubic perovskite structure $\mathrm{XYO}_{3}{ }^{60}$ or with slightly distorted variants of lower symmetry. These departures from the symmetric form are of great interest because of the dielectric and magnetic properties of these compounds. In the 'ideal' perovskite structure, which is cubic, the $X$ ions and the $O$ ions of nearly equal size, form a close-packed arrangement with the smaller $Y$ ions in some of the interstices. The sequence of layers in cubic close-packing is $\mathrm{ABCABC}$.... with the usual convention adopted in close-packing arrangements. The $\mathbf{X}$ ions are thus co-ordinated by twelve oxygen ions, the co-ordination polyhedron being the cubo-octahedron [Fig. $21(b)$ ]. The most common example of this structure is barium titanate $\mathrm{BaTiO}_{3}$ in which the co-ordinating atoms around barium are shown in Fig. $21(a) . \mathrm{BaTiO}_{3}$ is remarkable in having five crystalline forms. The simple cubic form is present between $120^{\circ} \mathrm{C}$. and $1460^{\circ} \mathrm{C}$. There is a high temperature form above $1460^{\circ}$. C. which is hexagonal. Between $120^{\circ} \mathrm{C}$. and $5^{\circ} \mathrm{C}$, the substance is tetragonal, between $5^{\circ} \mathrm{C}$. and $-80^{\circ} \mathrm{C}$. it is orthorhombic and below $-80^{\circ} \mathrm{C}$, it has a rhombohedral structure. The three forms below $120^{\circ} \mathrm{C}$, the Curie temperature, are ferroelectric. The changes in cell parameters, however, and the displacements 


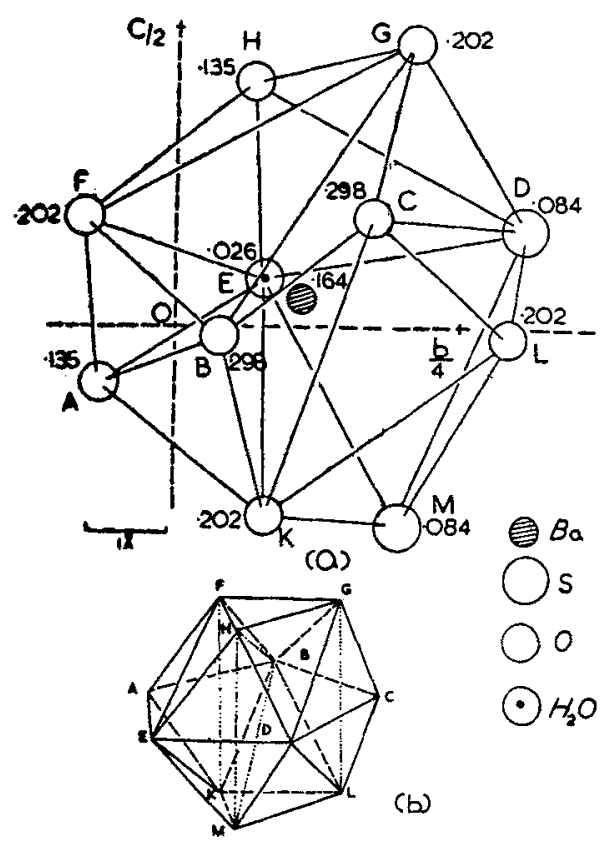

19
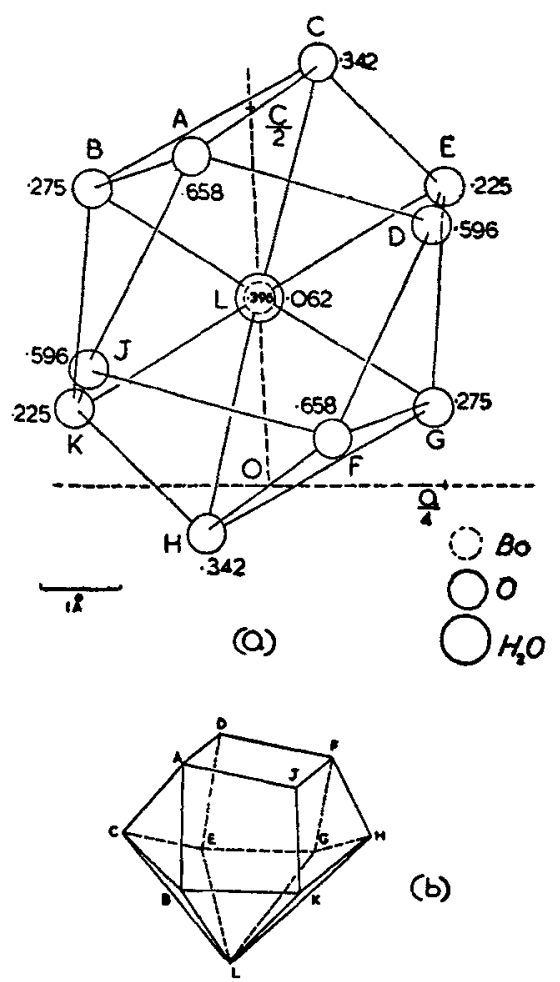

20

Fro. 19. Eleven-fold co-ordination of $\mathrm{Ba}^{2+}$ in $\mathrm{BaS}_{2} \mathrm{O}_{3}, \mathrm{H}_{2} \mathrm{O}$ (see text).

Fro. 20. Co-ordination polyhedron in $\mathrm{Ba}\left(\mathrm{CIO}_{2}\right)_{1} \cdot \mathrm{H}_{2} \mathrm{O}$.
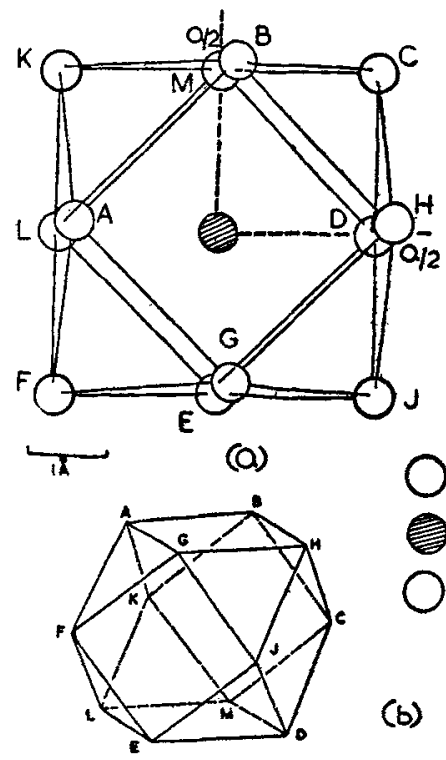

Oon now uno

Bant anaty

$\mathrm{O}_{\substack{\text { armengh } \\ \pm \frac{\mathrm{q}}{2}}}$

(b)

Frg. 21. Co-ordination polyhedron (Cubo-octahedron) in $\mathrm{BaTiO}_{4}$. 
of the atoms are extremely small and the environment of barium remains the same. Other examples of the cubic perovskite type are $\mathrm{BaYO}_{3}$ where $\mathrm{Y}=\mathrm{Zr}$, Sn, Ce, Hf, (Wells ${ }^{61}$ ), $\mathrm{Pr}$, Th (Wells ${ }^{62}$ ) and $\mathrm{U}^{63} \mathrm{~A}$ barium-iron oxide having the stoichiometric composition $\mathrm{BaFeO}_{3}$ with the cubic perovskite structure has also been reported, ${ }^{64} \mathrm{Fe}$ being in valence state $4^{+}$. Certain substituted perovskites ${ }^{65}$ such as $\mathrm{Ba}_{3} \mathrm{NiTa}_{2} \mathrm{O}_{9}, \mathrm{BaKTiNbO}_{6}, \mathrm{BaLaKTiAlNbO}_{9}$, $\mathrm{BaLiF}_{3}$ having ideal cubic or slightly distorted symmetry also crystallise in this structure. The barium atoms in $\mathrm{BaO}_{2} 2 \mathrm{TiO}_{2}$ are reported ${ }^{66}$ to be surrounded by twelve oxygens of the type found in cubic barium titanate. As seen already, in pseudocubic alkaline-earth molybdates and tungstates, which crystallise in the cryolite structure, two-thirds of the barium atoms in substances like $\mathrm{Ba}_{3} \mathrm{WO}_{6}$ and both the barium atoms in compounds of the type $\mathrm{Ba}_{2} \mathrm{CaWO}_{6}$ and $\mathrm{Ba}_{2} \mathrm{CaMoO}_{8}$ are co-ordinated by twelve oxygens which form a cubo-octahedron.

In the structure of the mineral psilomelane ${ }^{67}\left(\mathrm{Ba}, \mathrm{H}_{2} \mathrm{O}\right)_{2} \mathrm{Mn}_{5} \mathrm{O}_{10}$, with the ratio of $\mathrm{Ba}: \mathrm{H}_{2} \mathrm{O}=1: 2$ (the barium ions and water molecules are crystallographically indistinguishable), each $\left(\mathrm{Ba}, \mathrm{H}_{2} \mathrm{O}\right)$ is reported to be situated at the centre of 14 oxygen atoms, shown in Fig. 22, which form an irregular tetrahexahedron. The author reports that that it is more convenient to ignore the more distant $(>3.0 \AA)$ four atoms $\mathrm{P}, \mathrm{C}, \mathrm{Q}, \mathrm{F}$ which are coplanar with the central atom and describes the co-ordination in terms of a polyhedron formed by a prism and pyramid sharing one edge with adjacent members. However, it is seen that the $\mathrm{Ba}-\mathrm{O}$ distances increase progressively from $2.78 \AA$ to $3.16 \AA$ after which there is a gap, the two largest distances being $3.62 \AA$ and $3.76 \AA$. Therefore, it appears very reasonable to ignore the atoms $\mathbf{P}$ and $Q$ at these distances, in which case we find the co-ordination polyhedron consisting of eight oxygens A, G, B, H, M, D, F, Cand four waters $K, J, L, E$ to be a cubo-octahedron. The naming of atoms belonging to the cubooctahedron is the same as in Fig. $21(b)$. An error in the co-ordinates of $\mathrm{O}_{1}$ (Table I, page 435 of the original paper) which should be $0 \cdot 168,0,0.572$ instead of $0.168,0, \overline{0.072}$, as reported, should be pointed out here. The same co-ordination polyhedron is also present in the mineral hollandite, $\mathrm{BaMn}_{8} \mathrm{O}_{16 .}{ }^{68}$

The other type of close-packing, hexagonal close-packing, in which the sequence of close-packed layers is $\mathrm{ABAB}$... is displayed in hexagonal $\mathrm{BaNiO}_{3}{ }^{18}$ [(Fig. $23(a)$ ]. Here again the co-ordination number of barium is twelve, the polyhedron [Fig. $23(b)$ ] being known as the disheptahedron. $\mathrm{BaMnO}_{8}{ }^{69}$ also has the hexagonal close-packed arrangement of barium and 
oxygens at low temperatures. At high temperatures, however, the arrangement is close-packed but the sequence of layers is ABAC.... The high

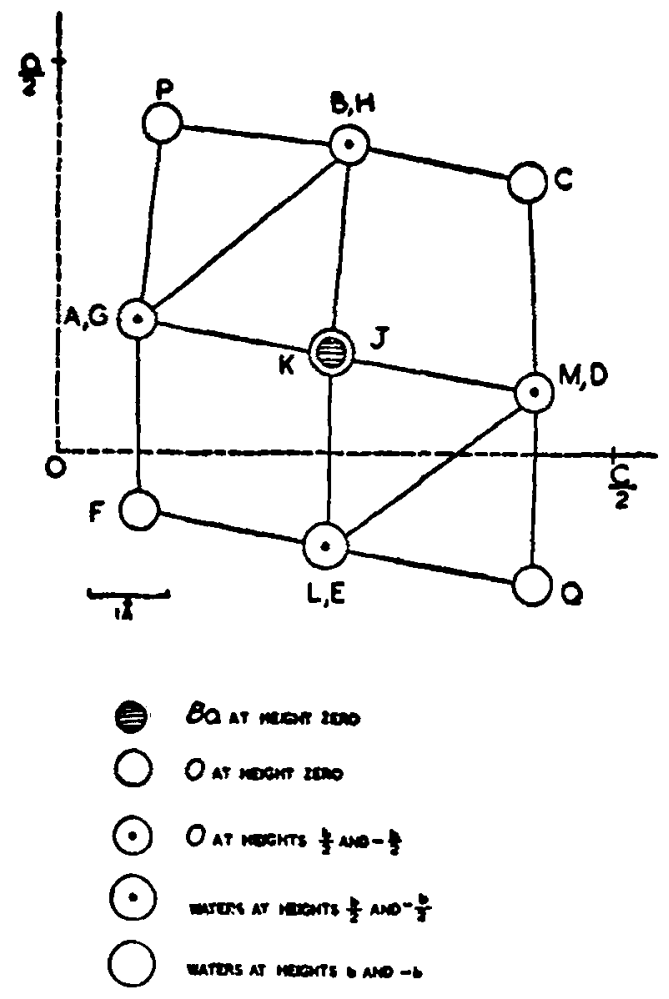

Fro. 22. Co-ordinating atoms round $\mathrm{Ba}^{2+}$ in $\left(\mathrm{Ba}, \mathrm{H}_{2} \mathrm{O}\right)_{2} \mathrm{Mn}_{8} \mathrm{O}_{20}$ (Cubo-octahedron).

temperature form of $\mathrm{BaTiO}_{3}{ }^{70}$ which exists at temperatures above $1460^{\circ} \mathrm{C}$. is closely related to the perovskite structure, the arrangement of close-packed $\mathrm{BaO}_{3}$ layers being $\mathrm{ABCACB} \ldots$.. In cases such as the last two mentioned, the cubic as well as hexagonal close-packing arrangements exist, depending on the layer in which the barium considered is present.

The structure of the isomorphous compounds ${ }^{71} \mathrm{Ba}_{5} \mathrm{Nb}_{4} \mathrm{O}_{15}$ and $\mathrm{Ba}_{5} \mathrm{Ta}_{4} \mathrm{O}_{16}$ have been described as a five layer $(\mathrm{ABCBC})$ repeat, closest packing of oxygens with a barium replacing an oxygen in each layer in the unit cell. The crystal strcutures of a number of new ferromagnetic compounds of barium belonging to the trigonal and hexagonal systems such as $\mathrm{BaFe}_{18} \mathrm{O}_{27}$, $\mathrm{Ba}_{2} \mathrm{Zn}_{2} \mathrm{Fe}_{12} \mathrm{O}_{22}$, etc., have been published. ${ }^{72,}{ }^{73}$ The structure of these compounds is related to the magnetoplumbite structure. In these structures, the oxygen and barium atoms together are reported to form a slightly expanded close-packed arrangement with $\mathrm{Ba}$ atoms in certain selected positions 
and smaller ions in certain of the holes. In $\mathrm{Ba} \mathrm{Fe}_{12} \mathrm{O}_{19}$ which is isomorphous with magnetoplumbite, the oxygen ions form a hexagonal close-packed lattice, some sites of which are occupied by barium. From powder diffraction studies and permittivity measurements at different temperatures over the entire range of composition, a tetragonal perovskite structure has been deduced for $(\mathrm{Pb}, \mathrm{Ba}) \mathrm{TiO}_{3}{ }^{74}$

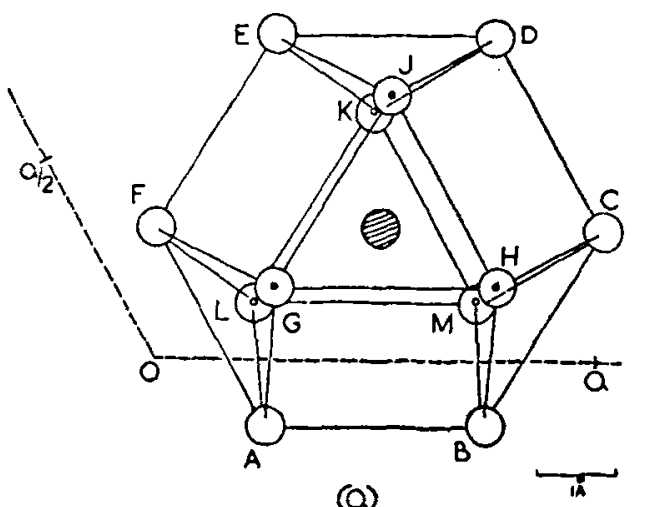

(a)

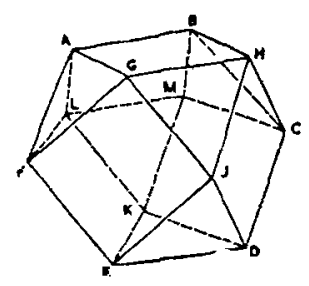

Bantrakert $\frac{20}{6}$

Oon $\frac{x}{4}$

Cont $\frac{c}{4}$

Cont $\frac{5 x}{4}$

(b)

23

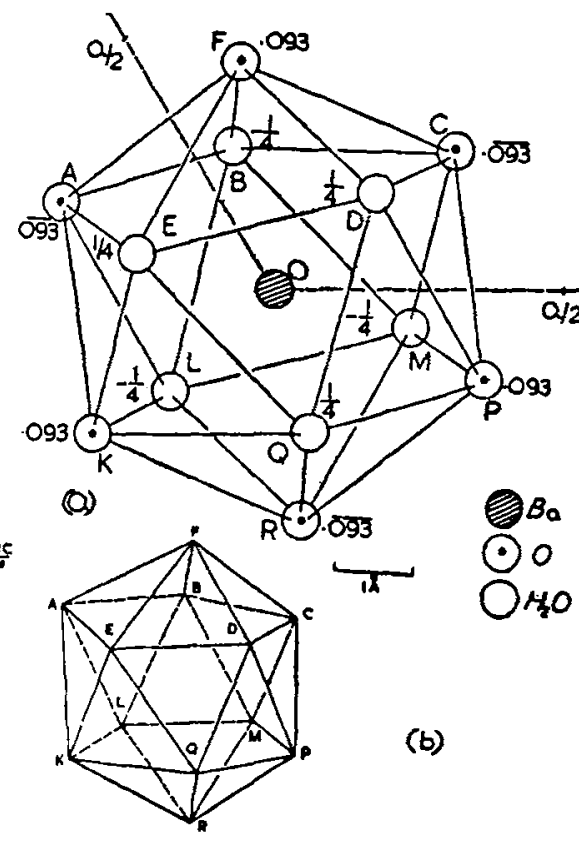

24

Fro. 23. Co-ordination polyhedron (Disheptabedron) in BaNio.

Fio. 24. Icosahedral co-ordination of barium in $\mathrm{Ba}\left(\mathrm{ClO}_{4}\right)_{2} \cdot 3 \mathrm{H}_{2} \mathrm{O}$.

The arrangement of six perchlorate oxygens and six waters round barium in the form of an icosahedron has been reported by Mani and Ramaseshan in barium perchlorate trihydrate $\mathrm{Ba}\left(\mathrm{ClO}_{4}\right)_{2} \cdot 3 \mathrm{H}_{2} \mathrm{O}$. The figure of the icosahedron is obtained by placing six spheres $\mathrm{F}$-ABCDE in a pentagonal pyramidal arrangement in contact with a similar group R-KLMPQ but with a rotation of $36^{\circ}$. The solid [Fig. $24(b)$ ] is bounded by twenty equilateral triangles and has six five-fold axes and ten three-fold axes. The icosahedron is one of the five regular solids ${ }^{75}$, the most symmetrical polyhedra having all their faces regular and alike and all the vertices surrounded in the same manner. The others are the tetrahedron, octahedron, cube and the pentagonal dodecahedron. $\mathrm{A}$ deformed icosahedral arrangement of oxygens round $\mathrm{Ba}^{2+}$ has 
been identified by the above authors in cubic $\mathrm{Ba}\left(\mathrm{NO}_{3}\right)_{2}{ }^{70}$ and also in the isomorphous complex fluorides, $\mathrm{BaXF}_{8},{ }^{77}$ where $\mathrm{X}=\mathrm{Si}, \mathrm{Ge}$ and $\mathrm{Ti}$. In the latter structures, the co-ordination polyhedron is made up of twelve fluorine ions. A highly distorted arrangement has been found by the present writers in barium peroxide dihydro-peroxidate $a-\mathrm{BaO}_{2} \cdot 2 \mathrm{H}_{2} \mathrm{O}_{2} \cdot{ }^{78}$

The icosahedron can also be described in terms of a chair-shaped hexagon AFCPRK [Fig. $24(b)$ ] with two triangles EDQ and BLM which are crossed with respect to each other placed symmetrically above and below it. On the other hand, in $\mathrm{Ba}_{3}\left(\mathrm{PO}_{2},{ }^{\mathrm{b}}\right.$ where barium ions of the second kind are surrounded by twelve oxygens as shown in Fig. $25(a)$, the hexagon is practically planar, the maximum difference in heights between the atoms in the plane being $0.17 \AA$; whereas in $\mathrm{Ba}\left(\mathrm{ClO}_{4}\right)_{2} \cdot 3 \mathrm{H}_{2} \mathrm{O}$ the difference in heights between the atoms $F, K$ or $P$ and $A, C$ or $R$ of the puckered hexagon is $1.8 \AA$. Therefore, the co-ordination polyhedron in the present case can be considered as a deformed icosahedron. The idealised solid is seen in Fig. $25(b)$. In
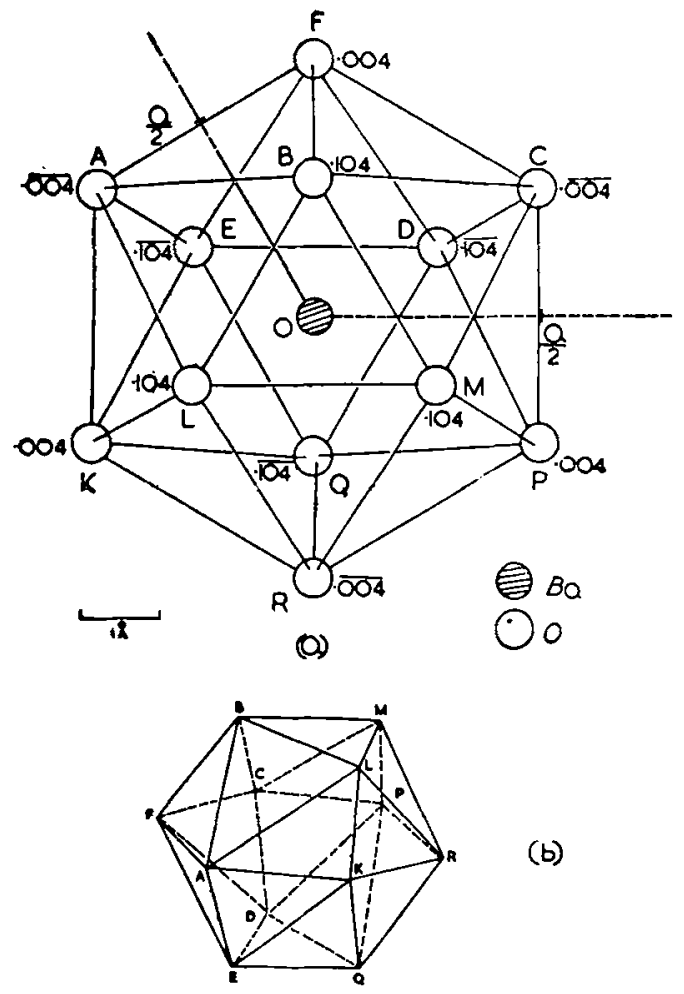

25

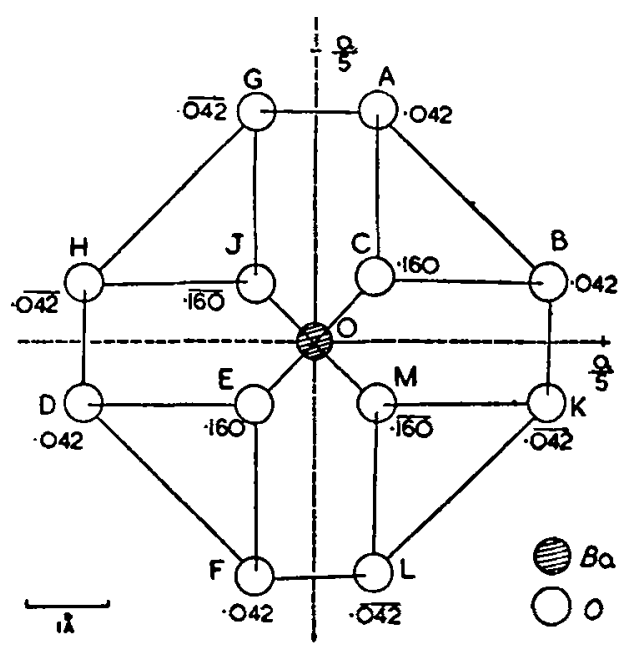

(a)

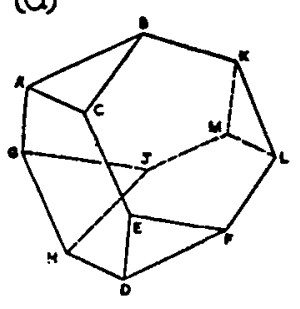

26

Fro. 25. Twelve-fold co-ordination of $\mathrm{Ba}_{\mathrm{u}}{ }^{2+}$ in $\mathrm{Ba}_{2}\left(\mathrm{PO}_{3}\right)_{2}$ (see text).

Fro. 26. Co-ordination polyhedron (Truncated tetrahedron) in $\mathrm{BaCa}_{2}\left(\mathrm{C}_{2} \mathrm{H}_{8} \mathrm{O}_{2}\right)_{6}$. 
cubic close-packing also (Fig. 21) there is a 3-6-3 arrangement of atoms round the cation, but the orientation of the triangles GHJ and KLM with respect to the plane hexagon ABCDEF is different. It has in fact been pointed out that the cubic close-packing arrangement can be converted into the icosahedral arrangement by the application of a force along a triad axis.

In barium dicalcium propionate $\mathrm{BaCa}_{2}\left(\mathrm{C}_{3} \mathrm{H}_{5} \mathrm{O}_{2}\right)_{8}{ }^{78}$ the co-ordination polyhedron when plotted [Fig. $26(a)$ ], is found to be a truncated tetrahedron. This solid, with four hexagonal and four triangular faces and twelve vertices, is shown in Fig. $26(b)$.

An unusual co-ordination polyhedron is the hexagonal prism which is present in hexagonal high temperature barium felspar $\mathrm{BaAl}_{2} \mathrm{Si}_{2} \mathrm{O}_{8}{ }^{80}$ (Fig. 27).

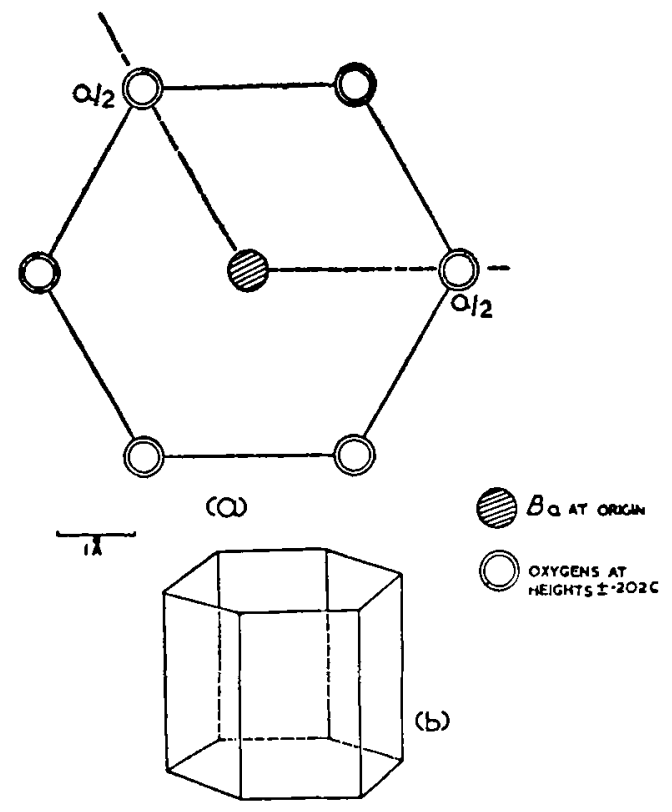

Fro. 27. Co-ordination polyhedron (Hexagonal prism) round $\mathrm{Ba}^{2+}$ in bigh temperature barium felspar $\left(\mathrm{BaAl}_{2} \mathrm{Si}_{2} \mathrm{O}_{2}\right)$.

In orthorhombic barite $\mathrm{BaSO}_{4},{ }^{81,82}$ the barium ion is co-ordinated by twelve oxygens at distances between $2.69 \AA$ and $3.32 \AA$, as seen in Fig. $28(a)$. These oxygen atoms form a new type of co-ordination polyhedron [Fig. $28(b)$ ] which can be described in terms of two boat-shaped hexagons $\mathrm{ABCDEF}$ and $\mathrm{ABGHJK}$ sharing a common edge $\mathrm{AB}$. The two lower edges $\mathrm{ED}$ and JH parallel to the common edge form a square. The hexagons are now centred on the outer side by atoms $L$ and $M$ such that 
these two along with $\mathrm{F}, \mathrm{K}, \mathrm{C}$ and $\mathrm{G}$ form a plane hexagon. The polyhedron thus resembles a basket with $\mathrm{AB}$ as the handle. Mani and Ramaseshan, in discussing the co-ordination of $\mathrm{Ba}^{2+}$ earlier, had reported the co-ordination number to be eight. The co-ordination polyhedron viewed down the $b$-axis as represented by these authors is shown in Fig. $28(\mathrm{c})$. The atoms which had not been taken into account are F, C, G and $\mathrm{K}$ and therefore, the polyhedron was reported to be a trigonal prism with its two vertical faces centred. A large number of substances crystallising in the $\mathrm{BaSO}_{4}$ structure like $\mathrm{KMnO}_{4}$, $\mathrm{KClO}_{4}, \mathrm{NH}_{4} \mathrm{ClO}_{4}, \mathrm{PbSO}_{4}, \mathrm{SrSO}_{4}\left(\mathrm{Wyckoff}^{83}\right)$, as also barium compounds like $\mathrm{BaBeF}_{4},{ }^{84} \mathrm{BaFeO}_{4},{ }^{85} \mathrm{BaBOF}_{3},{ }^{86} \mathrm{BaBeF}_{3} \mathrm{OH},{ }^{87} \mathrm{BaFPO}_{3},{ }^{83}$ etc., should display the same type of co-ordination of the metal ion, the co-ordinating atoms being oxygens, fluorines, hydroxyl groups or a combination of these as the case may be.
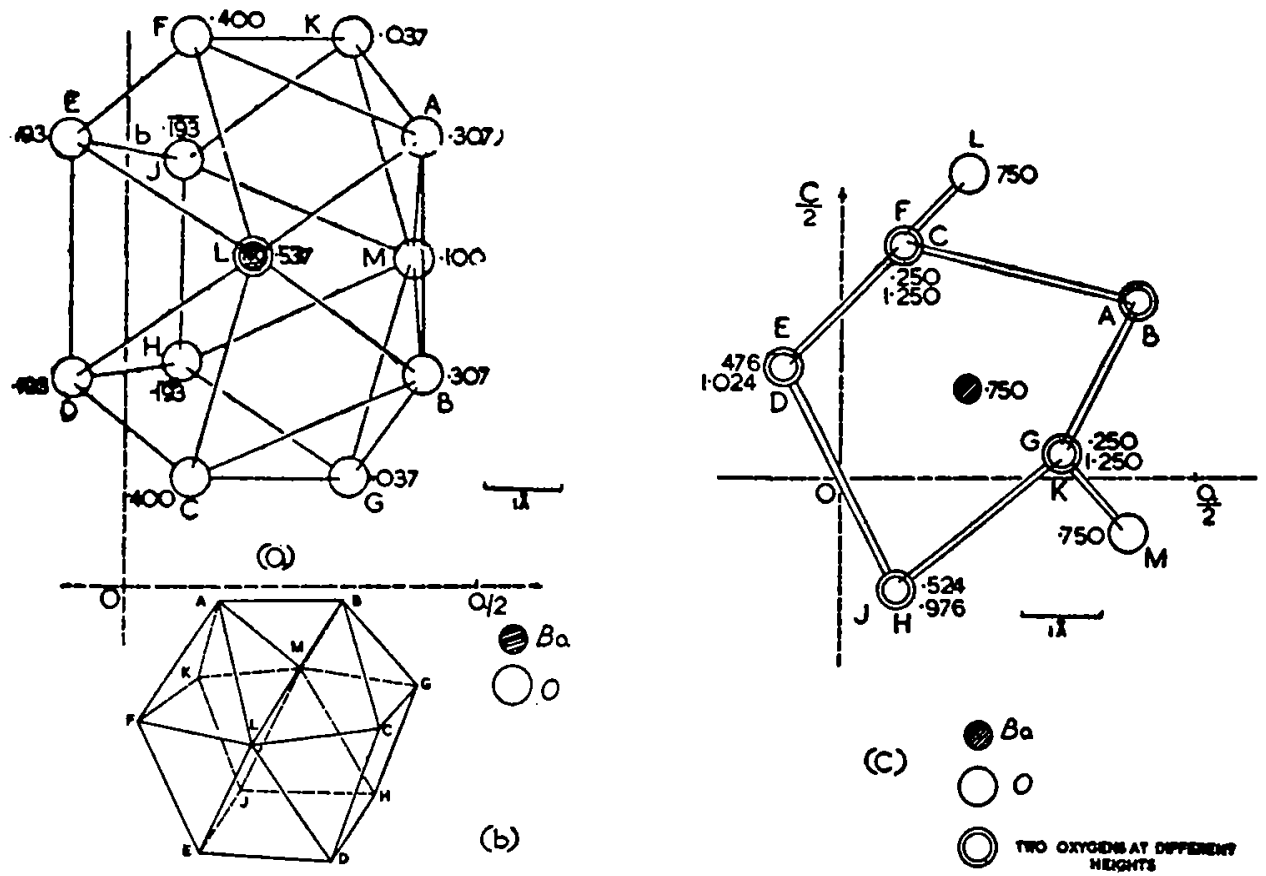

Fio. 28. New twelve-fold co-ordination of $\mathrm{Ba}^{2+}$ in $\mathrm{BaSO}_{4}$ (see text).

Table II gives the space group, cell dimensions, distances of co-ordinating atoms, C.N. and co-ordination polyhedra for most of the barium compounds that have been discussed. 


\section{TABLE II}

Distances of co-ordinating atoms, co-ordination numbers and polyhedra in barium compounds

\begin{tabular}{|c|c|c|c|c|c|}
\hline \multirow{2}{*}{ Compound } & \multirow{2}{*}{$\begin{array}{l}\begin{array}{c}\text { Space group and } \\
\text { cell dimensions } \\
(\mathrm{A})\end{array} \\
\begin{array}{l}\text { Fm3m } \\
a=5 \cdot 50\end{array}\end{array}$} & \multicolumn{2}{|c|}{$\begin{array}{c}\text { Ba-O } \\
\text { distances } \\
(\AA)\end{array}$} & \multirow{2}{*}{$\begin{array}{r}\text { C.N. } \\
6\end{array}$} & \multirow{2}{*}{$\begin{array}{c}\begin{array}{c}\text { Co-ordi- } \\
\text { nation } \\
\text { polyhedron }\end{array} \\
\begin{array}{c}\text { Octahedron, } \\
\text { Fig. } 1\end{array}\end{array}$} \\
\hline & & & 75 & & \\
\hline $\mathrm{BaTiSi}_{8} \mathrm{O}_{9}$ & $\begin{array}{l}\mathrm{P} 6 \mathrm{c} 2 \\
a=6 \cdot 60 \\
c=9 \cdot 71\end{array}$ & & 74 & 6 & $\begin{array}{l}\text { Distorted octa- } \\
\text { hedron }\end{array}$ \\
\hline $\begin{array}{l}\mathrm{BaGeO}_{2} \text { (High } \\
\text { temperature) }\end{array}$ & $\begin{array}{l}P 2_{1} 2_{1} 2_{1} \\
a=4 \cdot 58 \\
b=5 \cdot 68 \\
c=12 \cdot 76\end{array}$ & $\begin{array}{l}1 \times 2.62 \\
1 \times 2 \cdot 64 \\
1 \times 2.67 \\
1 \times 2 \cdot 79\end{array}$ & $\begin{array}{l}1 \times 2.84 \\
1 \times 2.94 \\
1 \times 2.99\end{array}$ & 7 & $\begin{array}{l}\text { Octahedron: } \\
+1 \text {, Fig. } 2\end{array}$ \\
\hline $\mathrm{Ba}_{2} \mathrm{ZnS}$ & $\begin{array}{l}\text { Pnam } \\
a=12 \cdot 05 \\
b=12 \cdot 65 \\
a=4 \cdot 21\end{array}$ & $\begin{array}{l}\mathrm{Ba}_{1}-\mathrm{S} \\
1 \times 3 \cdot 19 \\
2 \times 3 \cdot 22 \\
2 \times 3 \cdot 24 \\
2 \times 3 \cdot 26\end{array}$ & $\begin{array}{l}\mathrm{Ba}_{\mathrm{ni}}-\mathrm{S} \\
2 \times 3 \cdot 15 \\
2 \times 3 \cdot 20 \\
2 \times 3 \cdot 20 \\
1 \times 3 \cdot 22\end{array}$ & 7 & $\begin{array}{l}\text { Trigonal } \\
\text { prism, one face- } \\
\text { centred, Fig. } 3\end{array}$ \\
\hline $\mathrm{NiO} .3 \mathrm{~B} 2 \mathrm{O}$ & $\begin{array}{l}\mathbf{R}^{3} \mathrm{e} \\
\text { Hexagonal } \\
\text { axes: } \\
e=7 \cdot 85 \\
c=16 \cdot 50\end{array}$ & $2 \cdot 73$ & $-2 \cdot 88$ & 7 & $\begin{array}{l}\text { Modified penta- } \\
\text { gonal bipyra- } \\
\text { mid, Fig. } 4\end{array}$ \\
\hline $\mathbf{B a F}_{\mathbf{z}}$ & $\underset{a=6 \cdot 187}{\mathrm{Fm} 3 \mathrm{~m}}$ & & $\frac{-F}{69}$ & 8 & Cube \\
\hline $\mathrm{Ba}_{a}\left(\mathrm{Ti}_{\mathrm{g}-,}, \mathrm{Mg}_{\mathrm{g}}\right) \mathrm{O}_{16}$ & $\begin{array}{l}14 / \mathrm{m} \\
a=10 \cdot 11 \\
c=2 \cdot 936\end{array}$ & & & 8 & $\begin{array}{l}\text { Square prism, } \\
\text { Fig. } 5\end{array}$ \\
\hline $\mathrm{Ba}(\mathrm{OH})_{2} \cdot 8 \mathrm{H}_{2} \mathrm{O}$ & $\begin{array}{l}\mathrm{P} 2_{1} / \mathrm{n} \\
a=9 \cdot 35 \\
b=9 \cdot 28 \\
c=11 \cdot 87 \\
\beta=99^{\circ}\end{array}$ & $\begin{array}{l}1 \times 2 \cdot 69 \\
1 \times 2 \cdot 72 \\
2 \times 2 \cdot 73\end{array}$ & $\begin{array}{l}1 \times 2 \cdot 75 \\
1 \times 2 \cdot 76 \\
2 \times 2 \cdot 77\end{array}$ & 8 & $\begin{array}{l}\text { Archimedean } \\
\text { antiprism, } \\
\text { Fig. } 6\end{array}$ \\
\hline $\mathrm{BaO} . \mathrm{SiO}_{2} \cdot 6 \mathrm{H}_{2} \mathrm{O}$ & $\begin{array}{l}\mathrm{P} 2_{2} \mathrm{cn} \\
a=8 \cdot 43 \\
b=12.96 \\
c=15 \cdot 01\end{array}$ & $\begin{array}{l}\mathrm{Ba}_{\mathrm{I}} \\
2 \cdot 8\end{array}$ & $\begin{array}{l}0 \\
-2 \cdot 90\end{array}$ & 8 & $\begin{array}{l}\text { Archimedean } \\
\text { antiprism, } \\
\text { Fig. } 7\end{array}$ \\
\hline
\end{tabular}


Table II (Contd.)

\begin{tabular}{|c|c|c|c|c|c|}
\hline Compound & $\begin{array}{l}\text { Space group and } \\
\text { cell dimensions } \\
(\AA)\end{array}$ & \multicolumn{2}{|c|}{$\begin{array}{c}\text { Ba-O } \\
\text { distances } \\
(\AA)\end{array}$} & C.N. & $\begin{array}{l}\text { Co-ordi- } \\
\text { nation } \\
\text { polyhedron }\end{array}$ \\
\hline $\mathrm{BaFeSi}_{4} \mathrm{O}_{20}$ & $\begin{array}{l}\text { P4/nce } \\
a=7 \cdot 51 \\
c=16 \cdot 08\end{array}$ & \multicolumn{2}{|c|}{$\begin{array}{l}4 \times 2.73 \\
4 \times 2.98\end{array}$} & 8 & $\begin{array}{c}\text { Triangular } \\
\text { dodeca- } \\
\text { hedron, } \\
\text { Fig. } 9\end{array}$ \\
\hline $\mathrm{BaZnO}_{2}$ & $\begin{array}{l}P 3,21 \\
a=5 \cdot 886 \\
c=6 \cdot 734\end{array}$ & $\begin{array}{l}2 \times 2.64 \\
2 \times 2.68\end{array}$ & $\begin{array}{l}2 \times 2.97 \\
2 \times 3.36\end{array}$ & 8 & do. \\
\hline BaUO & $\begin{array}{l}\text { Pben } \\
a=5 \cdot 75 \\
b=8 \cdot 14 \\
c=8 \cdot 23\end{array}$ & $\begin{array}{l}4 \times 2 \cdot 71 \\
1 \times 2 \cdot 90\end{array}$ & $\begin{array}{l}2 \times 2.97 \\
1 \times 2.99\end{array}$ & 8 & $\begin{array}{l}\text { See Text, } \\
\text { Fig. } 10\end{array}$ \\
\hline $\mathrm{Ba}(\mathrm{MnO})_{2}$ & $\begin{array}{l}\text { Fddd } \\
a=14 \cdot 71 \\
b=11 \cdot 86 \\
c=7 \cdot 39\end{array}$ & \multicolumn{2}{|c|}{$\begin{array}{l}4 \times 2.4 \\
4 \times 2 \cdot 6\end{array}$} & 8 & $\begin{array}{l}\text { Orthorhombic } \\
\text { prism }\end{array}$ \\
\hline $\mathrm{NiO} \cdot \mathrm{BaO}$ & $\begin{array}{l}\text { Cmcm } \\
a=5 \cdot 73 \\
b=9 \cdot 20 \\
c=4 \cdot 73\end{array}$ & \multicolumn{2}{|c|}{$\begin{array}{l}4 \times 2.80 \\
4 \times 2.84\end{array}$} & 8 & $\begin{array}{l}\text { Quadrilateral } \\
\text { prism, Fig. } 11\end{array}$ \\
\hline $\mathrm{B}_{2} \mathrm{Cl}_{2} \cdot \mathrm{H}_{2} \mathrm{O}$ & $\begin{array}{l}\text { Pmcn } \\
a=4 \cdot 51 \\
b=9 \cdot 02 \\
c=11 \cdot 28\end{array}$ & $\begin{array}{l}\mathrm{Ba}-\mathrm{Cl} \\
2 \times 3 \cdot 14 \\
2 \times 3 \cdot 21 \\
1 \times 3 \cdot 32 \\
1 \times 3 \cdot 34 \\
1 \times 3 \cdot 38\end{array}$ & $\begin{array}{l}\mathrm{Ba}-\mathrm{H}_{2} \mathrm{O} \\
2 \times 2 \cdot 76\end{array}$ & 9 & $\begin{array}{l}\text { Trigonal prism } \\
\text { three faces } \\
\text { centred, } \\
\text { Fig. } 12(b)\end{array}$ \\
\hline $\mathrm{BaBr}_{2} \cdot \mathrm{H}_{2} \mathrm{O}$ & $\begin{array}{l}\text { Pmcn } \\
a=4 \cdot 59 \\
b=9 \cdot 41 \\
c=11 \cdot 59\end{array}$ & $\begin{array}{l}\mathrm{Ba}-\mathrm{Br} \\
2 \times 3.22 \\
2 \times 3.33 \\
1 \times 3.42 \\
1 \times 3.47 \\
1 \times 3.49\end{array}$ & $\begin{array}{l}\mathrm{Ba}-\mathrm{H}_{2} \mathrm{O} \\
2 \times 2.81\end{array}$ & 9 & do. \\
\hline $\mathrm{BaS}\left(\mathrm{S}_{2} \mathrm{O}_{2}\right)_{2} \cdot 2 \mathrm{H}_{2} \mathrm{O}$ & $\begin{array}{l}\text { Pnma } \\
a=5 \cdot 00 \\
b=10 \cdot 30 \\
c=21 \cdot 78\end{array}$ & $\begin{array}{l}\mathrm{Ba}-\mathrm{O} \\
2 \times 2.72 \\
2 \times 2.79 \\
2 \times 2.91\end{array}$ & $\begin{array}{l}\mathrm{Ba}-\mathrm{H}_{2} \mathrm{O} \\
1 \times 2 \cdot 65 \\
1 \times 2 \cdot 69 \\
1 \times 2.84\end{array}$ & 9 & do. \\
\hline
\end{tabular}


TABLE II (Contd.)

\begin{tabular}{|c|c|c|c|c|c|}
\hline \multirow{2}{*}{$\frac{\text { Compound }}{\mathrm{BaSe}\left(\mathrm{S}_{2} \mathrm{O}_{3}\right)_{2} \cdot 2 \mathrm{H}_{2} \mathrm{O}}$} & \multirow{2}{*}{$\begin{array}{c}\begin{array}{c}\text { Space group and } \\
\text { cell dimensions } \\
(\AA)\end{array} \\
\begin{array}{c}\text { Pnma } \\
a=4 \cdot 98 \\
b=10 \cdot 36 \\
c=22 \cdot 20\end{array}\end{array}$} & \multicolumn{2}{|c|}{$\begin{array}{c}\text { Ba-O } \\
\text { distances } \\
(\AA)\end{array}$} & \multirow{2}{*}{$\begin{array}{r}\text { C.N. } \\
9\end{array}$} & \multirow{2}{*}{$\begin{array}{c}\begin{array}{c}\text { Co-ordi- } \\
\text { nation } \\
\text { polyhedron }\end{array} \\
\begin{array}{c}\text { Trigonal prism } \\
\text { three faces }\end{array} \\
\text { centred, } \\
\text { Fig. } 12(b)\end{array}$} \\
\hline & & $\begin{array}{l}\mathrm{Ba}-\mathrm{O} \\
2 \times 2 \cdot 74 \\
2 \times 2 \cdot 81 \\
2 \times 2 \cdot 86\end{array}$ & $\begin{array}{l}\mathrm{Ba}-\mathrm{H}_{2} \mathrm{O} \\
1 \times 2 \cdot 51 \\
1 \times 2 \cdot 65 \\
1 \times 2 \cdot 74\end{array}$ & & \\
\hline $\mathrm{BaS}_{4} \mathrm{O}_{6} \cdot 2 \mathrm{H}_{2} \mathrm{O}$ & $\begin{array}{l}\mathrm{P} 2_{1} / \mathrm{c} \\
a=5 \cdot 17 \\
b=9 \cdot 46 \\
c=19 \cdot 07 \\
\beta=96^{\circ}\end{array}$ & \multicolumn{2}{|c|}{$2 \cdot 73-2 \cdot 90$} & 9 & do. \\
\hline $\mathrm{BaCl}_{2} \cdot 2 \mathrm{H}_{2} \mathrm{O}$ & $\begin{array}{l}\mathrm{P} 2_{1} / \mathrm{n} \\
a=6 \cdot 74 \\
b=10 \cdot 86 \\
c=7 \cdot 14 \\
\beta=90^{\circ} 57^{\prime}\end{array}$ & $\begin{array}{l}\mathrm{Ba}-\mathrm{Cl} \\
1 \times 3 \cdot 11 \\
1 \times 3 \cdot 16 \\
1 \times 3 \cdot 24 \\
1 \times 3 \cdot 27 \\
1 \times 3 \cdot 38\end{array}$ & $\begin{array}{l}\mathrm{Ba}-\mathrm{H}_{2} \mathrm{O} \\
1 \times 2 \cdot 78 \\
1 \times 2.80 \\
1 \times 2.81 \\
1 \times 2.82\end{array}$ & 9 & Fig. $12(a)$ \\
\hline $\mathrm{Ba}_{6} \mathrm{Ti}_{2} \mathrm{PtO}_{10}$ & $\begin{array}{l}\text { Abam } \\
a=13 \cdot 09 \\
b=13 \cdot 33 \\
c=5 \cdot 77\end{array}$ & $\begin{array}{l}\quad \mathrm{Ba} \\
1 \times 2 \cdot 71 \\
1 \times 2 \cdot 72 \\
2 \times 2.79\end{array}$ & $\begin{array}{l}-0 \\
2 \times 2.82 \\
1 \times 2.88 \\
2 \times 3.02\end{array}$ & 9 & $\begin{array}{l}\text { See Text } \\
\text { Fig. } 13\end{array}$ \\
\hline $\begin{array}{l}\mathrm{BaAl}_{2} \mathrm{Si}_{2} \mathrm{O}_{8} \\
\text { (Paracelcian) }\end{array}$ & $\begin{array}{l}\mathrm{P} 21_{1} / \mathrm{a} \\
a=9 \cdot 076 \\
b=9 \cdot 583 \\
c=8 \cdot 578 \\
\beta \approx 90^{\circ}\end{array}$ & $\begin{array}{l}2 \times 2.69 \\
2 \times 2.79 \\
1 \times 2.82 \\
2 \times 2.85 \\
2 \times 3.33\end{array}$ & & 9 & $\begin{array}{l}\text { Cube }+1 \text {, } \\
\text { Fig. } 14\end{array}$ \\
\hline $\begin{array}{l}\mathrm{BaAl}_{2} \mathrm{Si}_{2} \mathrm{O}_{2} \\
\text { (Celcian) }\end{array}$ & $\begin{array}{l}\mathrm{I} 2 / \mathrm{c} \\
a=8 \cdot 627 \\
b=13 \cdot 045 \\
c=14 \cdot 408 \\
\beta=115^{\circ} 13^{\prime}\end{array}$ & $\begin{array}{l}1 \times 2.667 \\
1 \times 2.902 \\
1 \times 2.939 \\
1 \times 3.135\end{array}$ & $\begin{array}{l}2 \times 2.850 \\
1 \times 2.909 \\
1 \times 3 \cdot 112 \\
1 \times 2.927\end{array}$ & 9 & $\begin{array}{l}\text { Cube }+1 \\
\text { Fig. } 14(b)\end{array}$ \\
\hline $\mathrm{BaCO}_{2}$ & $\begin{array}{l}\text { Pnma } \\
a=5 \cdot 28 \\
b=8 \cdot 83 \\
c=6.39\end{array}$ & & $\begin{array}{l}2 \cdot 76 \\
2 \cdot 80 \\
2 \cdot 84\end{array}$ & 9 & do. \\
\hline $\begin{array}{l}\mathrm{BaSi}_{2} \mathrm{O}_{5} \\
\text { (Sanbornite) }\end{array}$ & $\begin{array}{l}\text { Pcmn } \\
a=4 \cdot 63 \\
b=7 \cdot 69 \\
c=13.53\end{array}$ & $\begin{array}{l}7 \times(2 \cdot 74 \\
2 \times 3 \cdot 14\end{array}$ & $-2 \cdot 94)$ & 9 & do. \\
\hline
\end{tabular}


TABLE II (Contd.)

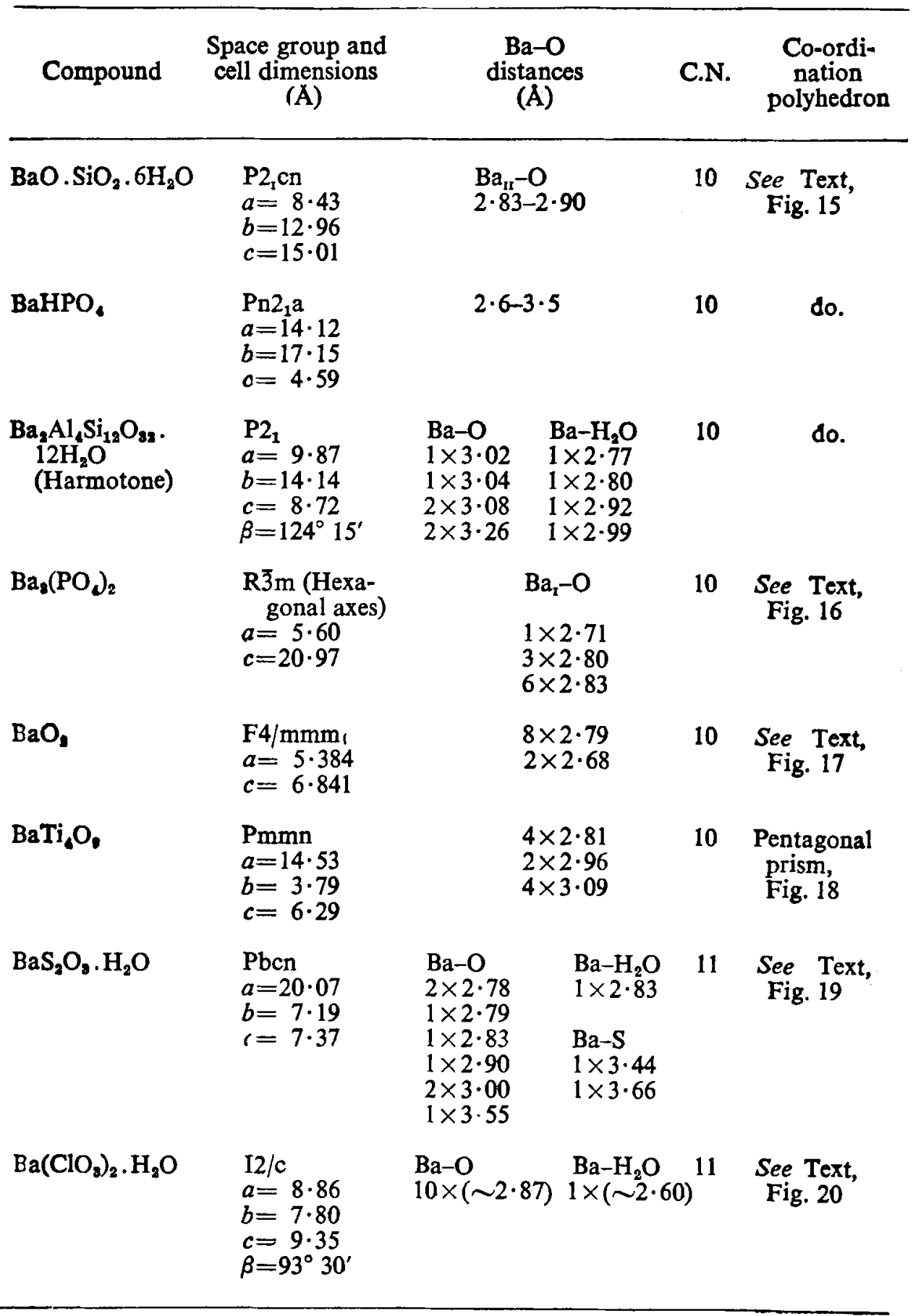


TABLE II (Contd.)

\begin{tabular}{|c|c|c|c|c|c|}
\hline Compound & $\begin{array}{l}\text { Space group and } \\
\text { cell dimensions } \\
(\AA)\end{array}$ & \multicolumn{2}{|c|}{$\begin{array}{c}\text { Ba-O } \\
\text { distances } \\
(\AA)\end{array}$} & C.N. & $\begin{array}{l}\text { Co-ordi- } \\
\text { nation } \\
\text { polyhedron }\end{array}$ \\
\hline $\begin{array}{l}\mathrm{BaTiO}_{2} \text { (Cubic } \\
\text { perovskite) }\end{array}$ & $\begin{array}{l}\text { Pm 3m } \\
a=3.986\end{array}$ & \multicolumn{2}{|c|}{$2 \cdot 82$} & 12 & $\begin{array}{l}\text { Cubo-octa- } \\
\text { hedron, } \\
\text { Fig. } 21\end{array}$ \\
\hline $\begin{array}{l}\left(\mathrm{Ba}, \mathrm{H}_{2} \mathrm{O}\right)_{2} \cdot \mathrm{Mn}_{5} \\
\mathrm{O}_{10}(\text { Psilo- } \\
\text { melane) }\end{array}$ & $\begin{array}{l}\mathrm{A} 2 / \mathrm{m} \\
a=9 \cdot 56 \\
b=2 \cdot 88 \\
c=13 \cdot 85 \\
\beta=92^{\circ} 30^{\prime}\end{array}$ & $\begin{array}{l}\mathrm{Ba}-\mathrm{O} \\
2 \times 2 \cdot 85 \\
2 \times 2 \cdot 91 \\
2 \times 2 \cdot 96 \\
1 \times 3 \cdot 00 \\
1 \times 3 \cdot 16\end{array}$ & $\begin{array}{l}\mathrm{Ba}-\mathrm{H}_{2} \mathrm{O} \\
2 \times 2 \cdot 78 \\
2 \times 2 \cdot 88\end{array}$ & 12 & $\begin{array}{c}\text { do. } \\
\text { Fig. } 22\end{array}$ \\
\hline $\begin{array}{l}\mathrm{BaMn}_{8} \mathrm{O}_{16} \\
\text { (Hollandite) }\end{array}$ & $\begin{array}{l}\mathrm{I} 4 / \mathrm{m} \\
a=9.96 \\
c=2.86\end{array}$ & \multicolumn{2}{|c|}{$\begin{array}{l}8 \times 2 \cdot 74 \\
4 \times 3 \cdot 31\end{array}$} & 12 & $\begin{array}{l}\text { Cubo-octa- } \\
\text { hedron, } \\
\text { Fig. } 21\end{array}$ \\
\hline BaNiO, & $\begin{array}{l}\text { C6mc } \\
a=5 \cdot 58 \\
c=4 \cdot 832\end{array}$ & \multicolumn{2}{|c|}{$\begin{array}{l}6 \times 2.79 \\
6 \times 2.90\end{array}$} & 12 & $\begin{array}{l}\text { Dishepta- } \\
\text { hedron, } \\
\text { Fig. } 23\end{array}$ \\
\hline $\begin{array}{r}\mathrm{BaMnO}_{8} \text { (low } \\
\text { temperature) }\end{array}$ & $\begin{array}{l}\mathrm{P} 6_{2} \mathrm{mc} \\
a=5 \cdot 67 \\
c=4 \cdot 71\end{array}$ & \multicolumn{2}{|c|}{$\begin{array}{l}6 \times 2 \cdot 84 \\
6 \times 2 \cdot 86\end{array}$} & 12 & do. \\
\hline $\begin{array}{c}\mathrm{BaMnO}_{8} \text { ( } \mathrm{High} \\
\text { temperature) }\end{array}$ & $\begin{array}{l}\mathrm{P} 6_{\mathrm{a}} / \mathrm{mmc} \\
a=5 \cdot 67 \\
c=9 \cdot 38\end{array}$ & \multicolumn{2}{|c|}{$\begin{array}{l}6 \times 2.83 \\
6 \times 2.86\end{array}$} & 12 & See Text. \\
\hline $\begin{array}{l}\mathrm{BaTiO}_{8} \text { (non- } \\
\text { ferroelectric) }\end{array}$ & $\begin{array}{l}\mathrm{C6} / \mathrm{mmc} \\
a=5 \cdot 735 \\
c=14 \cdot 05\end{array}$ & $\begin{array}{l}\mathrm{Ba}_{1}-\mathrm{O} \\
6 \times 2 \cdot 89 \\
6 \times 2 \cdot 94\end{array}$ & $\begin{array}{l}\mathrm{Ba}_{12}-\mathrm{O} \\
6 \times 2.88 \\
3 \times 2.78 \\
3 \times 2.96\end{array}$ & 12 & See Text. \\
\hline $\mathrm{Ba}_{5} \mathrm{Ta}_{4} \mathrm{O}_{16}$ & $\begin{array}{l}\mathrm{P} 3 \mathrm{ml} \\
a=5 \cdot 79 \\
c=11 \cdot 75\end{array}$ & \multicolumn{2}{|c|}{$2 \cdot 7-3 \cdot 0$} & 12 & See Text. \\
\hline $\mathrm{Ba}_{8} \mathrm{Zn}_{2} \mathrm{Fe}_{12} \mathrm{O}_{2}$ & $\begin{array}{l}\mathrm{R} 3 \mathrm{~m} \text { (Hexa- } \\
\text { gonal axes) } \\
a=5 \cdot 876 \\
c=43 \cdot 558\end{array}$ & \multicolumn{2}{|c|}{$\begin{array}{l}3 \times 2 \cdot 80 \\
6 \times 2 \cdot 94 \\
3 \times 3 \cdot 19\end{array}$} & 12 & See Text. \\
\hline $\mathrm{Ba}(\mathrm{ClO})_{2} \cdot 3 \mathrm{H}_{2} \mathrm{O}$ & $\begin{array}{l}\mathrm{PG}_{3} \text { or } \mathrm{P} 6_{8} / \mathrm{m} \\
\mathrm{a}=7 \cdot 278 \\
c=9.64\end{array}$ & $\begin{array}{l}\mathrm{Ba}-\mathrm{O} \\
3 \times 2 \cdot 96 \\
3 \times 3 \cdot 18\end{array}$ & $\begin{array}{l}\mathrm{Ba}-\mathrm{H}_{2} \mathrm{O} \\
6 \times 3 \cdot 03\end{array}$ & 12 & $\begin{array}{l}\text { Icosabedron, } \\
\text { Fig. } 24\end{array}$ \\
\hline
\end{tabular}


TABLE II-Contd.

\begin{tabular}{|c|c|c|c|c|}
\hline Compound & $\begin{array}{c}\text { Space group and } \\
\text { cell dimensions } \\
(\AA)\end{array}$ & $\begin{array}{c}\text { Ba-O } \\
\text { distances } \\
(\AA)\end{array}$ & C.N. & $\begin{array}{l}\text { Co-ordi- } \\
\text { nation } \\
\text { polyhedron }\end{array}$ \\
\hline $\mathrm{Ba}\left(\mathrm{NO}_{3}\right)_{2}$ & $\begin{array}{l}\mathrm{Pa} 3 \\
a=8 \cdot 11\end{array}$ & $\begin{array}{l}6 \times 2.82 \\
6 \times 3 \cdot 00\end{array}$ & 12 & $\begin{array}{l}\text { Icosohedron } \\
\text { Fig. } 24\end{array}$ \\
\hline BaSiF, & $\begin{array}{l}\mathrm{R} 3 \mathrm{~m} \\
a=4 \cdot 75 \\
a=97^{\circ} 58^{\prime}\end{array}$ & $\begin{array}{l}\mathrm{Ba}-\mathrm{F} \\
6 \times 2 \cdot 75 \\
6 \times 2 \cdot 88\end{array}$ & 12 & do. \\
\hline $\mathrm{B} 2 \mathrm{GeF}$. & $\begin{array}{l}\mathrm{R} 3 \mathrm{~m} \\
a=4 \cdot 83 \\
a=98^{\circ} 1^{\prime}\end{array}$ & $\begin{array}{l}\mathrm{Ba}-\mathrm{F} \\
6 \times 2.77 \\
6 \times 2.92\end{array}$ & 12 & do. \\
\hline$a-\mathrm{BaO}_{2} \cdot 2 \mathrm{H}_{2} \mathrm{O}_{2}$ & $\begin{array}{l}C 2 / c \\
a=8 \cdot 454 \\
b=6 \cdot 398 \\
c=8 \cdot 084 \\
\beta=96^{\circ} 32^{\prime}\end{array}$ & $\begin{array}{l}2 \times 2.68 \\
2 \times 2.74 \\
2 \times 2.78 \\
2 \times 2.86 \\
2 \times 2.93 \\
2 \times 2.97\end{array}$ & 12 & do. \\
\hline $\mathrm{Ba}_{2}\left(\mathrm{PO}_{4}\right)_{2}$ & $\begin{array}{l}\mathrm{R} 3 \mathrm{~m} \text { (Hexa- } \\
\text { gonal axes) } \\
a=5.60 \\
c=20.97\end{array}$ & $\begin{array}{l}\mathrm{Ba}_{\mathrm{xI}}-\mathrm{O} \\
6 \times 3 \cdot 23 \\
6 \times 2 \cdot 80\end{array}$ & 12 & $\begin{array}{l}\text { See Text, } \\
\text { Fig. } 25\end{array}$ \\
\hline $\mathrm{BaCa}_{8}\left(\mathrm{C}_{2} \mathrm{H}_{6} \mathrm{O}_{2}\right)_{6}$ & $\begin{array}{l}\mathrm{Fd} 3 \mathrm{~m} \\
a=18 \cdot 20\end{array}$ & $3 \cdot 10$ & 12 & $\begin{array}{l}\text { Truncated } \\
\text { tetrahedron, } \\
\text { Fig. } 26\end{array}$ \\
\hline $\begin{array}{c}\mathrm{BaAl}_{2} \mathrm{Si}_{2} \mathrm{O}_{8} \text { (High } \\
\text { temperature } \\
\text { barium felspar) }\end{array}$ & $\begin{array}{l}6 / \mathrm{mmm} \\
a=5 \cdot 25 \\
c=7 \cdot 84\end{array}$ & $3 \cdot 05$ & 12 & $\begin{array}{l}\text { Hexagonal } \\
\text { prism, } \\
\text { Fig. } 27\end{array}$ \\
\hline $\mathrm{BaSO}_{4}$ & $\begin{array}{l}\text { Pnma } \\
a=8 \cdot 85 \\
b=5 \cdot 43 \\
c=7 \cdot 13\end{array}$ & $\begin{array}{ll}1 \times 2.69 & 2 \times 2.94 \\
1 \times 2.76 & 2 \times 3.10 \\
2 \times 2.77 & 2 \times 3.32 \\
2 \times 2.80 & \end{array}$ & 12 & $\begin{array}{l}\text { See Text, } \\
\text { Fig. } 28\end{array}$ \\
\hline
\end{tabular}

\section{Discussion}

Table III (Pauling ${ }^{88}$ ) shows the co-ordination for representative cations to be expected on the basis of radius-ratios. These have generally been 
verified to be true in actual structures. Potassium, however, is seen to display several different types of co-ordination. As the present survey shows the barium ion also exhibits a rich veriety of co-ordination.

TABLE III

Values of the ligancy for cations with oxygen ion

(After Pauling)

\begin{tabular}{|c|c|c|c|c|c|}
\hline Ion & & & $\begin{array}{l}\text { Radius } \\
\text { ratio }\end{array}$ & $\begin{array}{l}\text { Predicted } \\
\text { ligancy }\end{array}$ & $\begin{array}{l}\text { Observed } \\
\text { ligancy }\end{array}$ \\
\hline $\mathrm{B}^{2+}$ & . & .. & $0 \cdot 20$ & 3 or 4 & 3,4 \\
\hline $\mathrm{Be}^{2+}$ & .. & .. & 0.25 & 4 & 4 \\
\hline $\mathrm{Li}^{+}$ & .. & .. & $0 \cdot 34$ & 4 & 4 \\
\hline $\mathrm{Si}^{4}$ & . & .. & $0 \cdot 37$ & 4 & 4,6 \\
\hline $\mathrm{Al}^{3+}$ & .. & . & $0 \cdot 41$ & 4 or 6 & $4,5,6$ \\
\hline $\mathrm{Ge}^{4+}$ & .. & . & 0.43 & 4 or 6 & 4,6 \\
\hline $\mathrm{Mg}^{2+}$ & .. & .. & 0.47 & 6 & 6 \\
\hline $\mathrm{Na}^{+}$ & .. & .. & 0.54 & 6 & 6,8 \\
\hline $\mathrm{Ti}^{4+}$ & .. & .. & 0.55 & 6 & 6 \\
\hline $\mathrm{Sc}^{8+}$ & .. & .. & 0.60 & 6 & 6 \\
\hline$Z^{2+}$ & .. & .. & 0.62 & 6 or 8 & 6,8 \\
\hline $\mathrm{Ca}^{2+}$ & . & .. & 0.67 & 8 & $7,8,9$ \\
\hline $\mathrm{Ce}^{4+}$ & . & .. & 0.72 & 8 & 8 \\
\hline $\mathbf{K}^{+}$ & . & .. & 0.75 & 9 & $6,7,8,9,10,12$ \\
\hline $\mathrm{Cs}^{+}$ & .. & .. & 0.96 & 12 & 12 \\
\hline
\end{tabular}

The values in antique are those usually found for the cation.

The other values are observed only in a few crystals.

In the earlier work of Goldschmidt ${ }^{89}$ and Pauling, ${ }^{1}$ only closed polyhedra formed by the nearest neighbours were considered. However, to obtain closed polyhedra in more complex crystals, it is necessary to take into account not merely the atoms which are the nearest neighbours, but also those which are next nearest ones. The question naturally arises as to the limit to the cation-anion distance one should go. Such limits have been set uptil now purely by convenience and not because they are dictated by any physical considerations. 
The question why an ion sometimes prefers a higher co-ordination than usual still rcmains to be satisfactorily answered. The radius-ratios for the alkali halides (Wclls ${ }^{90}$ ) and for the alkaline-earth metals in relation to $\mathrm{O}, \mathrm{S}, \mathrm{Se}$ and Te are shown in Tables IV and $\mathrm{V}$ respectively. The salts which are expected to crystallise in the rocksalt structure are enclosed in full lines.

TABLE IV

Values of radius ratio for the alkali halides

(After Wells)

\begin{tabular}{|c|c|c|c|c|c|}
\hline & $\mathrm{Li}$ & $\mathrm{Na}$ & $\mathbf{K}$ & $\mathbf{R b}$ & C. \\
\hline$F$ & 0.44 & 0.70 & 0.98 & $0.92^{*}$ & $0.81^{*}$ \\
\hline $\mathrm{Cl}$ & 0.33 & 0.52 & 0.73 & 0.82 & 0.93 \\
\hline $\mathrm{Br}$ & 0.31 & 0.49 & 0.68 & 0.76 & 0.87 \\
\hline 1 & $0 \cdot 28$ & 0.44 & 0.62 & 0.69 & 0.78 \\
\hline
\end{tabular}

- Where $r_{A}$, radius of the cation, is greater than $r_{X}$, radius of the anion, $r_{x} / r_{A}$ is given.

TABLE $\mathrm{V}$

Values of univalent radius ratio for alkaline earth metals

\begin{tabular}{lllll}
\hline & $\mathrm{Ca}$ & $\mathrm{Sr}$ & $\mathrm{Ba}$ \\
\hline $\mathrm{S}$ & 0.67 & 0.75 & 0.87 \\
$\mathrm{~S}$ & 0.54 & 0.60 & 0.70 \\
$\mathrm{Se}$ & 0.51 & 0.57 & 0.66 \\
$\mathrm{Te}$ & 0.47 & 0.53 & 0.61 \\
\hline
\end{tabular}

Crystals with radius ratios enclosed by full lines are expected to crystallise with $\mathrm{NaCl}$ structure.

Except those enclosed by broken lines which have the $\mathrm{CsCl}$ structure, the rest of the crystals exhibit the rocksalt structure. 
As Wells ${ }^{91}$ points out, it is not clear why salts like $\mathrm{RbBr}, \mathrm{RbCl}, \mathrm{CsF}$ as also SrO do not adopt the $\mathrm{CsCl}$ type of structure with a larger co-ordination number eight, or why $\mathrm{KF}, \mathrm{RbF}$ and $\mathrm{BaO}$ do not prefer still higher co-ordination of the cations. The difference between the lattice energy for $\mathrm{NaCl}$ and $\mathrm{CsCl}$ types of structures is too small to account for the structural differences. One could enumerate all possible factors such as the variation in the Madelung constant, effective charge, the repulsion exponent, etc., on which the inter-ionic distance and hence the co-ordination number depends to a greater or smaller degree. Co-ordination in complex ionic crystals is not entirely a geometrical problem of radii and sizes but also depends on the polarisation of the ions. Thus $\mathrm{Ba}^{2+}$ is itself highly polarisable unlike other smaller positive ions and this must be responsible for the large variety in its co-ordination. Although the factors that affect the inter-atomic distances are well known, a quantitative assessment of their eftects in any specific crystal is in our present state of knowledge not possible.

In many crystals the positive ion plays a vital role in determining the structure. The unique co-ordination polyhedron round that positive ion is an important factor in the geometry of the crystal architecture. $\mathbf{B a}^{2+}$ ion shows a bewildering number of co-ordination polyhedra. Whatever be the reasons for this, one cannot but conclude that the barium ion does not play a primary role in deciding the structure as most other ions do Indeed its role is comparatively secondary and it enters the vacant spaces in the structure provided by the other atoms of the crystal.

\section{SUMMARY}

A systematic study has been made of the crystal co-ordination of the barium ion in various compounds whose structures have been solved. Apart from the more common co-ordination polyhedra which are enumerated in text-books, a number of new polyhedra have been identified, particularly in cases where the co-ordination numbers are unusual, such as ten or eleven. According to the radius-ratio rule of Pauling, a co-ordination number of nine or ten is normally expected for the barium ion. The present investigations, however, reveal that it shows a variety of co-ordinations with ligancies from six up to twelve. Some of the factors that might possibly enter in explaining this wide range of co-ordination numbers are discussed. It appears as though the part played by the $\mathrm{Ba}^{2+}$ ion in deciding the structure is secondary, limiting itself only to occupying vacant spaces provided by other atoms in the crystal. 


\section{ACKNOWLEDGEMENT}

The authors thank Professor R. S. Krishnan for his kind interest in this investigation. Thanks are also due to Dr. N. V. Mani for his assistance in the earlier part of this study.

\section{REFERENCES}

1. Pauling, $\mathrm{L}$.

2. Mani, N. V. and Ramaseshen, $\mathbf{S}$.

3. Manohar, $H$. and Ramaceshan, $\mathrm{S}$.

4.

5. Wells, A. F.

6. Wyckof, R. W. G.

7. Faivre, $\mathbf{R}$.

8. Hilmer, $W$.

9. Dornberzer-Schiff, $\mathrm{K}$.

10. Zachariason, W. H.

11. Vannertére, N. G.

12. Wells, A. F.

13.

14. Steward, E. G. and Rooksby, H. P.

15. Wells, A. F.

16.

17. Schnering, H. G. and Hoppo, $\mathrm{R}$.
.. "The principles determining the structures of complex ionic crystals," J. Amer. Chem. Soc., 1929, 51, 1010-26.

"The crystal structure of barium perchlorate trihydrate $\mathrm{Ba}\left(\mathrm{ClO}_{1}\right)_{2} \cdot 3 \mathrm{H}_{2} \mathrm{O}$ and the crystal co-ordination of $\mathrm{Ba}^{++}$ion," Z. Kristallogr, 1960, 114, 200-14.

"The crystal structure of $\mathrm{Ba}(\mathrm{OH})_{2} .8 \mathrm{H}_{2} \mathrm{O}$ and the crystal co-ordination of the barium ion," Curr. Sci., 1963, 32, $248-49$.

.. "The crystal structure of barium hydroxide octahydrate, $\mathrm{Ba}(\mathrm{OH})_{2} .8 \mathrm{H}_{2} \mathrm{O}, " Z$. Kristallogr., 1964, 119, 357.

.. Structral Inorganic Chemsitry, Clarendon Press, Oxford, 1962 , p. 462.

.. The Structure of Crystals, Supplement, Reinhold Publishing Corporation, New York, 1935, p. 16.

.. Structure Reports (N.V.A. Oosthoek's Uitgevers Mij, Utrecht) 1945-46, 10, 173-74.

. "Die Structur der Hochtemperaturform des Bariumgermanates, $\mathrm{BaGeO}_{2}$ (h)," Acta Cristallogr., 1962, 15, 1101-05.

.. "The symmetry and structure of $\operatorname{Sr}\left(\mathrm{GeO}_{\mathrm{s}}\right)$ as a structure mode for a-Wollastonite CaSiO, ," Kristallografia, 1961, 6, 859-68. English translation in Soviet Physics Crystallography. 1962, 6, 694-700.

. "The crystal structure of benitoite $\mathrm{BaTiSi}_{8} \mathrm{O}_{8}, "$ Z. Kristallogr. $1930,74,139.46$.

. "The structure of barium peroxide monohydroperoxidate," Arkiv Kemi, 1959, 14, 149-59.

. Structrural Inorganic Chemistry, Clarendon Press, Oxford, 1962 , p. 680.

.. Ibid., 1962, p. 499

"Pseudo-cubic alkaline-earth tungstates and molybdates of the $\mathrm{R}_{\mathbf{3}} \mathrm{MX}_{6}$ type," Acta Crystallogr., 1951, 4, 503-07.

.. Structural Inorganic Chemistry, Clarendon Press, Oxford, 1962 , p. 369.

. . Ibid., 1962, p. 74.

"Zur Kenntnis des $\mathrm{Ba}_{\mathrm{Z}} \mathrm{ZnS}_{\mathrm{p}}, " Z$, anorg, allg. Chem., 1961, 312, 99-109, 
18. Lander, J. J.

.. "The crystal structures of $\mathrm{NiO} .3 \mathrm{BaO}$, NiO. BaO, BaNiO and intermediate phases with composition near $\mathrm{Ba}_{2} \mathrm{Ni}_{2} \mathrm{O}_{4}$; with a note on NiO." Acta Crystallogr., 1951, 4, 148-56.

19. Wells, A. F.

.. Structural Inorganic Chemistry, Clarendon Press, Oxford 1962 , p. 337.

20. Dryden, J. S. and Wadsley, "The structure and dielectric properties of compounds with A. D. the formula $\mathrm{Ba}_{2}\left(\mathrm{Ti}_{8-}, \mathrm{Mg}_{z}\right) \mathrm{O}_{10}$," Trans. Faraday Soc., 1958, 54, 1574-80.

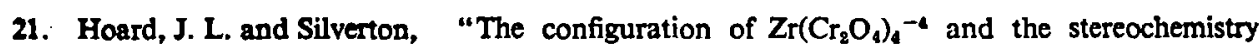
G. L. of discrete eight-co-ordination," J. Amer. Chem. Soc., 1961, 83, 4293-295.

22. Pauling, $\mathbf{L}$.

.. The Nature of the Chemical Bond, Cornell University Press, Ithaca, 1960, p. 544.

23. Hohne, E. and Dornberger- "Die Kristallstruktur des Wasserhaltigen Barium-Silikats Schiff, $\mathbf{K}$. BaO. $\mathrm{SiO}_{2} .6 \mathrm{H}_{2} \mathrm{O}$," Acta Crystallogr., 1961, 14, 1298.

24. Pabst, A.

"Crystal structure of gillespite, $\mathrm{BaFeSi}_{4} \mathrm{O}_{10}$," Structure Reports, 1942-44, 9, 249-50.

25. Wyckoff, R. W. G. $\quad$. Crystal Structures, Vol. II, Interscience Publishers, New York, Chap. 8, Text page 6, Table page 13 .

26. Schnering, H. G., Hoppe, R. and Zemann, J.

"Die Kristallstruktur des $\mathrm{BaZnO}_{2}$," Z.anorg. allg. Chem., 1960, 305, 241-54.

27. Phillips, F. C.

.. Introduction to Crystallography, Longmans, Green and Co., 1956, p. 115.

28 Spitsbergen, U.

"The crystal structures of $\mathrm{BaZnO}_{2}, \mathrm{BaCoO}_{2}$ and $\mathrm{BaMnO}_{2}$,", Acta Crystallogr., 1950, 13, 197-98.

29. Samson, S. and Sillen, L. G.

"Die Kristallstruktur des Bariumuranates," Structure Reports, 1947-48, 11, 441-43.

30. Hardy, A., Piekarski, C. "Structure cristalline du permanganate de baryum," Comptes and Hagen-Muller, M. P. rendus, 1959, 249, 2579-581.

31. Wells, A. F.

.. Structural Inorganic Chemistry, Clarendon Press, Oxford, 1962 , p. 338.

32. Wagner, G. and Binder, $\mathrm{H}$. "Untersuchung der binären Systeme $\mathrm{BaO}_{-} \mathrm{SnO}_{2}$ und $\mathrm{BaO}-\mathrm{PbO}_{2}$. Part II. Kristallstruktur-bestimungen," $Z$. anorg. allg. Chem., 1959, 298, 12-21.

33. Jensen, A. T.

.. "On the structure of $\mathrm{SrCl}_{2} .6 \mathrm{H}_{2} \mathrm{O}$," Structure Reports, 1940-41, 8, 133-34.

34. Wyckoff, R. W. G.

.. The Structure of Crystals, Supplement, Reinhold Publishing Corporation, New York, 1935, p. 83.

35 Vainstein, B. K. and Pinsker, Z. G.

"Electronographic determination of the structure of barium chloride monohydrate," Structure Reports, 1949, 12, 160-61.

36.

.. "Electronographic study of barium bromide monohydrate," Zhur. Fiz. Khim., 1950, 24, 432-36.

37. Foss, $O$ : and Zachariasen, H.

"The crystal structure of barium pentathionate dihydrate," Structure Reports, 1954, 18, 499-502. 
38. Foss, $C$. and Tjomsland, $O$, "The crystal structure of barium seleno-pentathionate dihyd: rate" Ibid., 1954, 18, 496-97.

39. - Furberg, S. and Zachariasen, $H$.

"The crystal structure of barium tetrathionate dihydrate," lbid., 1954, 18, 494-96.

40. Jensen, A. T.

.. "The structure of $\mathrm{BaCl}_{2} .2 \mathrm{H}_{8} \mathrm{O}$," lbid., 1945-46, 10, 95-96.

41. Blattner, H., Gränicher, H., "Die Kristallstruktur des hexagonalen und rhombischen Kanzig, W. and Merz, W.

42. Smith, J. V.

. "The crystal structure of paracelcian, $\mathrm{BaAl}_{8} \mathrm{Si}_{2} \mathrm{O}_{8}, "$ Acta, Crystallogr., 1953, 6, 613-20.

43. Newnham, R. E. and Megaw, H. D.

"The crystal structure of celcian (Barium Felspar)," Ibld., 1960, 13, 303-12.

44. Colby, M. Y. and Lacoste, L. J. B.

"The crystal structure of witherite," $Z$. Kristallogr., 1935, 90, 1-7.

45. Wyckoff, R. W. G.

. The Structure of Crystals, Reinhold Publishing Corporation, New York, 1931, pp. 272-75.

46. Douglass, R. M.

. "The crystal structure of Sanbornite, $\mathrm{BaSi}_{3} \mathrm{O}_{3}, "$ Amer. Mimeral, 1958, 43, 517-36.

47. Lander, J. J.

"Polymorphism and anion rotational disorder in alkaline-earth carbonates," J. Chem. Phys., 1949, 17, 892-901.

48. Wells, A. F.

- Structural Inorganic Chemistry, Clarendon Press, Oxford, 1962, p. 73.

49. Burley, G.

"Crystal structure of barium hydrogen orthophosphate," J. Res. Nat. Bur. Stand., 1958, 60, 23-27.

50. Sadanaga, R., Marumo, F and Takeuchi, $Y$.

"The crystal structure of Harmotone, $\mathrm{Ba}_{2} \mathrm{Al}_{6} \mathrm{Si}_{12} \mathrm{O}_{32} \cdot 12 \mathrm{H}_{2} \mathrm{O}$," Acta Crystallogr., 1961, 14, 1153-63.

51. Zachariasen, W. H.

"The crystal structure of the normal orthophosphates of barium and strontium," Ibid., 1948, 1, 263-65.

52. Scholder, R. and Klemm, W.

Structure Reports, 1954, 18, 526-27.

53. Abrahams, S. C. and Kalnajs, J.

"The crystal structure of barium peroxide," Acta Crystallogr., 1954, 7, 838-42.

54. Wells, A. F.

. Structural Inorganic Chemistry, Clarendon Press, Oxford, 1962, p. 761.

55. Templeton, D. H. and Dauben, C. H.

"Polarized octahedra in barium tetratitanate," J. Chem. Phys., 1960, 32, 1515-18.

56. Nardelli, M. and Fava, G. "The crystal structure of barium thiosulphate monohydrate," Acta Crystallogr, 1962, 15, 477-84.

57. Wells, A. F.

Structural Inorganic Chemistry, Clarendon Press, Oxford, 1962, pp. 341-42.

58. Kartha, $\mathbf{G}$.

"Structure of halogenates of the type $\mathrm{A}\left(\mathrm{BO}_{3}\right)_{2} \cdot \mathrm{H}_{\mathbf{2}} \mathrm{O}$. I. Barium chlorate monohydrate, $\mathrm{Ba}\left(\mathrm{ClO}_{3}\right)_{2}, \mathrm{H}_{2} \mathrm{O}$," Proc. Ind. Acad. Sci., 1952, 36 A, 501-29. 
59. Kartha, G.

.. "Structure of halogenates of the type $A\left(\mathrm{BO}_{2}\right)_{2} . \mathrm{H}_{2} \mathrm{O}$. Barium bromate monohydrate $\mathrm{Ba}\left(\mathrm{BrO}_{3}\right)_{2} . \mathrm{H}_{2} \mathrm{O}$," Ibid, 1953, $38 \mathrm{~A}, 1-12$.

60. Wells, A. F.

.. Structural Inorganic Chemistry, Clarendon Press, Oxford, 1962, pp. 494-96.

61.

. I Ibid., 1962, p. 496.

62.

.. Structural Inorganic Chemistry, Second Edition, Clarendon Press, Oxford, 1950, p. 377.

63. Rudorff, W. and Pfitzer, F. Structure Reports, 1954, 18, 466.

64. Derbyshire, S. W., Fraker, "A barium-iron oxide with the perovskite structure," Acta A. C. and Stadelmaier, Crystallogr., 1961, 14, 1293-94.

H. $\mathrm{H}$.

65. Roy, R.

"Multiple ion substitution in the perovskite lattice," Structure Reports, 1954, 18, 439-40.

66. Harrison, F. W.

. "The crystal structure of barium dititanate $\mathrm{BaO} .2 \mathrm{TiO}_{2}, "$ Acta Crystallogr., 1956, 9, 495-500.

67. Wadsley, A. D.

.. "The crystal structure of psilomelane $\left(\mathrm{Ba}, \mathrm{H}_{2} \mathrm{O}\right)_{2} \mathrm{Mn}_{3} \mathrm{O}_{10}$," Ibid., 1953, 6, 433-38.

68. Byström, A. and Byström, A. $M$.

"The crystal structure of Hollandite, the related manganeae dioxide minerals and a-MnO,", Ibid., 1950, 3, 146-54.

69. Hardy, A.

.. "Structures Crystallines de Deux Variétiés Allotropiques de Manganite de Baryum. Nouvelle Sructure ABO," Ibld., 1962, 15, 179-81.

70. Wells, A.F.

.. Structural Inorganic Chemistry, Clarendon Press, Oxford, 1962, p. 494.

71. Galasso, F. and Katz, L. .. "Preparation and structure of $\mathrm{Ba}_{6} \mathrm{Ta}_{6} \mathrm{O}_{15}$ and related compounds," Acta Crystallogr., 1961, 14, 647-50.

72. Went, J. J., Rathenau,

G. W., Gorter, E. W. and van Oosterhout, G. W.

"Ferroxdure, a class of new permanent magnet materials," Philips Tech. Rev., 1951-52, 13, 194-208.

73. Braun, P. B.

"The crystal structures of a new group of ferromagnetic compounds," Philips Res. Rep., 1957, 12, 491-548.

74. Shirane, G., Hoshino, S. and Suzuki, K.

"Crystal structures of lead titanate and lead-barium titanate," J. Phy. Soc. Japan, 1950, 5, 453-55.

75. Wells, A. F.

Structural Inorganic Chemistry, Clarendon Press, Oxford, 1962, p. 96.

76. Jaeger, F. M. and van Melle, F. A.

"On the symmetry and structure of the cubic nitrates of calcium, strontium, barium and lead," Proc. Acad. Sci., Ansterdam, 1928, 31, 651-55.

77. Hoard, J. L. and Vincent, W, B,

"Structures of complex fluorides: Barium fluosilicate and barium:fluogermanate," J. Amer. Chem. Soc., 1940, 62, 3126-29. 
78. Vannerberg, N. G. _. "The system $\mathrm{BaO}_{2}-\mathrm{H}_{2} \mathrm{O}-\mathrm{H}_{2} \mathrm{O}_{2}$. III. The crystal structures of $a-, \beta$ - and $\gamma$-barium peroxide dihydroperoxidate and barium peroxide monohydroperoxidate dihydrate," Arkiv Kemi, 1959, 14, 125-45.

79. Nitta, I. and Watanabe, T. "Crystal structure of barium dicalcium propionate," Sc!. Papers Inst. Phys. Chem. Research (Tokyo), 1935, 26, 164-77.

80. Yoshiki, B. and Matsumoto, $\mathbf{K}$.

"High temperature modification of barium felspar," Structure Reports, 1951, 15, 304-05.

81. James, R. W. and Wood, W. A.

"The crystal structure of barytes, celestine and anglesite," Proc. Roy. Soc. (Lond.), 1925, 109 A, 598-620.

82. Manohar, $\mathrm{H}$.

.. "Refinement of the atomic co-ordinates of BaSO" (Unpublished).

83. Wyckoff, R. W. G. _. Crystal Structures, Vol. II, Interscience Publishers, New York, Chap. 8, Table p. 21.

84. Rollier, M. A.

. "Dimensioni della cella elementare del fluoberillato di bario," Gazz. Chim. Ital., 1954, 84, 663-66.

85. Scholder, R., Bunsen, H. v., Kindervater, $F$. and Weiss, $W$.

"Zur Kenntnis der Ferrate (VD)," Z. anorg. allg. Chem., 1955, 282, 268-79.

86. Chackraburtty, D. M. .. “The structure of $\mathrm{BaBOF}_{3}$," Acta Crystallogr., 1957, 10, 199-200.

87. Mitra, $G$.

.. "Hydroxyfluoberyllates. Part II. Hydroxyfluoberyllates of $\mathrm{Ca}, \mathrm{Ba}, \mathrm{Sr}, \mathrm{Pb}, \mathrm{Ce}, \mathrm{La}$ and $\mathrm{Hg}$," J. Indian Chem. Soc., $1955,32,246-48$.

88. Pauling, L.

... The Nature of the Chemical Bond, Cornell University Press, Ithaca, 1960 , p. 546.

89. Goldschmidt, V. M. -. "Geochemische Vesteilungsgesetze der Elemente," Skrifter Norske Videnskaps-Akad, Oslo. I. Mat. Naturv. KI., 1926.

90. Wells, A. F.

... Structural Inorganic Chemistry, Clarendon Pross, Oxford, 1962, p. 76.

91.

. Ibid., 1962, pp. 76-77. 